\title{
Species-specific biomass allometric models and expansion factors for indigenous and planted forests of the Mozambique highlands
}

\author{
Tarquinio Mateus Magalhães ${ }^{1}$. \\ Victoria Norberto Cossa ${ }^{1}$ • Benard Soares Guedes ${ }^{1}$. \\ Amélia Saraiva Monguela Fanheiro²
}

Received: 19 February 2020 / Accepted: 4 April 2020 / Published online: 26 May 2020

(C) The Author(s) 2020

\begin{abstract}
Secondary Miombo woodlands and forest plantations occupy increasing areas in Mozambique, the former due to anthropogenic activities. Plantations, mainly species of Eucalyptus and Pinus, are being established on sites previously covered by secondary Miombo woodlands. This affects the evolution, cycle and spatiotemporal patterns of carbon (C) storage and stocks in forest ecosystems. The estimation of $\mathrm{C}$ storage, which is indispensable for formulating climate change policies on sequestrating $\mathrm{CO}_{2}$, requires tools such as biomass models and biomass conversion and expansion factors (BCEF). In Mozambique, these tools are needed for both indigenous forests and plantations. The objective of this study is to fit species-specific allometric biomass models and BCEF for exotic and indigenous tree species. To incorporate efficient inter-species variability, biomass equations were fitted using nonlinear mixed-effects models. All tree component biomass models had good predictability; however, better predictive accuracy and ability was observed for the 2-predictors biomass model with tree height as a
\end{abstract}

Project funding: The work was funded partly by the Swedish International Cooperation Agency (SIDA).

The online version is available at https://www.springerlink.com.

Corresponding editor: Tao Xu.

Tarquinio Mateus Magalhães

tarqmag@yahoo.com.br; tarquinio_magalhaes@uem.mz

1 Departamento de Engenharia Florestal, Faculdade de Agronomia e Engenharia Florestal, Universidade Eduardo Mondlane, Campus Universitário, Edifício no. 1, 257, Maputo, República de Moçambique

2 Departamento de Sociologia Rural, Escola Superior de Desenvolvimento Rural, Universidade Eduardo Mondlane, Vilankulo, República de Moçambique second predictor. The majority of the variability in BCEF was explained by the variation in tree species. Miombo species had larger crown biomass per unit of stem diameter and stored larger amounts of biomass per stem volume. However, due to relatively rapid growth, larger stem diameters, heights, and stand density, the plantations stored more biomass per tree and per unit area.

Keyword Biomass allometry · Biomass partitioning · Miombo $\cdot$ Exotic forest plantations $\cdot$ Brachystegia spiciformis $\cdot$ Julbernardia globiflora $\cdot$ Eucalyptus $\cdot$ Pinus

\section{Introduction}

Forests sequester one third of carbon dioxide $\left(\mathrm{CO}_{2}\right)$ emissions from fuel and land use changes (Houghton 2007; Pan et al. 2011), store large amounts of carbon (C) in vegetation and soils, are sources of $\mathrm{C}$ when disturbed or destroyed by anthropogenic or natural causes, and become atmospheric $\mathrm{C}$ sinks during forest growth after disturbance (Brown et al. 1999). Land use changes are associated with ecosystem C change (Fan et al. 2016) and are the second largest cause of $\mathrm{C}$ losses after fossil fuel combustion (Fu et al. 2010; LozanoGarcía and Parras-Alcántara 2013).

Miombo is the main and most extensive forest type in southern Africa (Ribeiro et al. 2015), and in Mozambique, it comprises about two-thirds of the country's forested land (Aquino et al. 2018). Secondary Miombo woodlands and forest plantations have been occupying increasing areas in Mozambique, the former due to anthropogenic activities. Plantations, mainly species of Eucalyptus and Pinus (Blid 2014), are being established in areas previously occupied by secondary Miombo woodlands, where shrubs and small trees predominate due to past exploitation (Magalhães 2014). This 
land use change, from natural forest cover to plantations, may affect the evolution, cycle and spatiotemporal patterns of $\mathrm{C}$ storage and stocks in forest ecosystems. Estimation of $\mathrm{C}$ storage over time and space is indispensable for formulating climate change policies on sequestrating $\mathrm{CO}_{2}$ (Chen et al. 2019), and requires developing tools such as biomass models and biomass conversion and expansion factors (BCEF).

Biomass allocation patterns and tree allometry are widely affected by tree architecture (Coll et al. 2008; Trubat et al. 2012). However, tree species may differ greatly in architecture (Ketterings et al. 2001). Biomass allocation and tree allometry also vary with stand characteristics, e.g., density and composition (Zhang et al. 2015; Fang et al. 2018). Consequently, generic models (mixed-species models) are unlikely to yield accurate biomass estimates compared to species-specific ones (Vieilledent et al. 2012; Annighöfer et al. 2016; Goussanou et al. 2016); i.e., species-specific models are preferred over generic ones. Thus, when modelling biomass, species-specific effects need to be incorporated in order to account for inter-species variability. One efficient way of incorporating inter-subject variability is through mixed-effects models.

To quantify the impact that planting exotic species on former secondary Miombo lands has on carbon sequestration, biomass models and estimates are required for both Miombo species and exotic species. Because the exotic species are predominantly species of Eucalyptus (e.g., E. cloeziana F. Muell.) and Pinus (e.g., P. elliottii Engelm., $P$. patula Schltdl. \& Cham., P. taeda L.) and the Miombo species comprise mainly Brachystegia spiciformis Benth. and Julbernardia globiflora (Benth.), biomass equations on these species are indispensable.

This research aimed to: (1) fit species-specific allometric biomass models and biomass conversion and expansion factors (BCEF) for exotic and indigenous species; and, (2) test the allometric universal scaling law between aboveground biomass and diameter at breast height (DBH).

\section{Materials and methods}

\section{Experimental site}

The study area is in the Machipanda locality in the central province of Manica, in the Inhamacarri Forest owned by Machipanda Agroforestry Centre of the Eduardo Mondlane University. The Forest is located between $32^{\circ} 37^{\prime} 30^{\prime \prime}$ and $32^{\circ} 42^{\prime} 43^{\prime \prime} \mathrm{E}$ and $25^{\circ} 54^{\prime} 15^{\prime \prime}$ and $25^{\circ} 56^{\prime} 40^{\prime \prime} \mathrm{S}$, and is in hilly terrain with altitudes varying from 1400 to $1700 \mathrm{~m}$ a.s.l. Mean annual temperature is about $21^{\circ} \mathrm{C}$ and mean annual precipitation is estimated at $1300 \mathrm{~mm}$ (Guedes et al. 2018). Soils are mainly deep, intensely weathered Ferralsols and slight to moderately weathered Cambisols with weak horizontal differentiation (Guedes et al. 2018).

The indigenous forests are small-sized trees of B. spiciformis, J. globiflora, and Uapaca kirkiana Müll. Arg. and the plantations are monocultures of Pinus (P. taeda, P. elliotti, and P. patula), Eucalyptus (E. cloeziana, E. grandis W. Hill, and E. camaldulensis Dehnh.) and more recently, Araucaria spp. The plantations were established on former wet Miombo soils (Guedes et al. 2016).

\section{Data acquisition}

The target species with $\mathrm{DBH} \geq 5 \mathrm{~cm}$ were the Miombo species B. spiciformis and J. globiflora, and plantations of $E$. cloeziana, P. taeda, P. elliotti, and P. patula (Table 1). A total of 120 trees, distributed among the species as shown in Table 1, were randomly selected, their diameters measured, and harvested.

Total heights $(\mathrm{H})$ were recorded, and the trees divided into aboveground biomass (AGB) components, stem and crown. The stem was defined as the length of the trunk from a predefined stump height of $20 \mathrm{~cm}$ to a top diameter of $2.5 \mathrm{~cm}$. The crown was the sum of branches, foliage, seeds, flowers, and the remaining portion of the stem, from the $2.5 \mathrm{~cm}$ diameter height to the tip of the tree.

The stem was dived into five equal segments and the diameter measured at the midpoint. After fresh-weighting each segment, a disc sample was removed from the top, fresh weighted, oven-dried at $105{ }^{\circ} \mathrm{C}$ to constant mass, and subsequently re-weighed. The dry mass of the whole segment was then obtained by multiplying the ratio of oven dry to fresh mass of the disc by the fresh mass of the segment. The dry mass of the stem (stem biomass), was the sum of the dry masses of the constituent segments. The volume of the stem was computed using Hohenadl's formula (Magalhães and Seifert 2015a).

For logistical reasons and to ensure the largest sample size, the foliage was not separated from the branches, as it is a time-demanding task. The crown was fresh weighed, a sample was collected, weighed in the field, and oven-dried in the laboratory. To ensure proportionality in sampling, the primary branches were divided in coarse $(\varnothing \geq 5 \mathrm{~cm})$, and fine $(\varnothing<5 \mathrm{~cm})$, where $\varnothing$ is the diameter of the branch at the insertion point on the stem. For each size class, a primary branch with mid diameter was selected and a $3-5 \mathrm{~cm}$ disc removed from the insertion point. A portion of the twigs, leaves, flowers, and fruits of each primary branch was collected. The crown sample, therefore, consisted of the discs, twigs, leaves, flowers, and fruit from the selected branches. The dry mass of the crown was obtained similarly to that for each stem segment. The total aboveground biomass (AGB) was the sum of the dry masses of the stem and crown. 


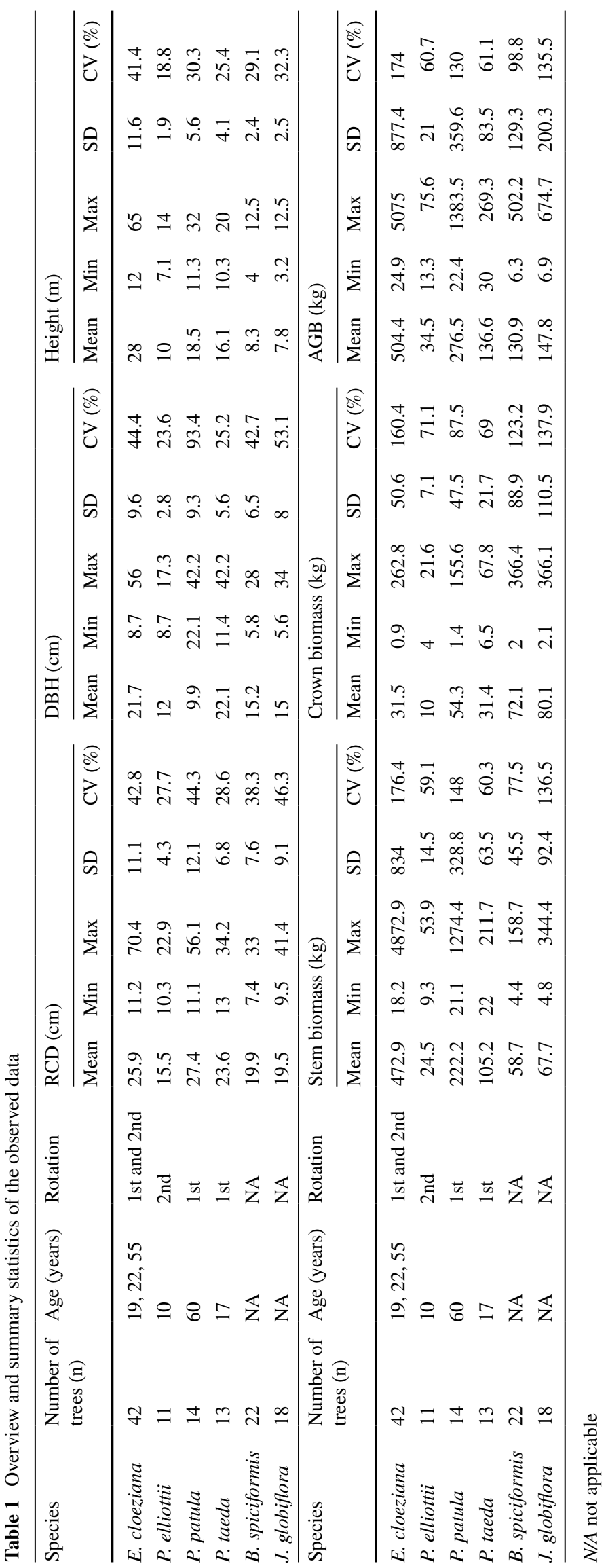




\section{Data analysis}

Tree component biomass models were fitted using nonlinear regression, being preferred over linear ones because biomass is a nonlinear function of stem diameter and height (Schroeder et al. 1997; Ter-Mikaelian and Korzukhin 1997; Bolte et al. 2004; Salis et al. 2006). Power or allometric functions, as an extension of nonlinear functions, were preferred over other forms of nonlinear functions because growing plants maintain the proportions between different parts, e.g., between tree biomass and predictive biometric variables such as DBH and tree height (Pilli et al. 2006). Allometric growth is observed when a constant ratio or proportion is maintained between the growth rates of different parts of the plant (Enquist 2002; Opik and Rolfe 2005). This is observed between biomass and the easily measurable variables DBH and height (Zianis and Mencuccini 2004; Fehrmann and Kleinn 2006; Pilli et al. 2006). Biomass allometric functions are represented as $y=b x^{k}$, where $y$ represents tree or component biomass, $x$ an easily measurable tree variable, $k$ is the ratio of growth rate between $y$ and $x$, and $b$ is the scaling coefficient. The ratio of growth rate is the scaling exponent (Zianis and Mencuccini 2004; Fehrmann and Kleinn 2006; Packard and Boardman 2008). Because both the scaling coefficient and the scaling exponent vary with species (Pilli et al. 2006) as a result of varying architecture and wood density (Ketterings et al. 2001), species-specific allometric models; are preferred over general ones. Architecture influences biomass allocation and allometry (Coll et al. 2008; Trubat et al. 2012). Therefore, biomass models were fitted using nonlinear mixed-effects (NLME) models to incorporate inter-species variability. The general form of NLME models is:

$Y_{i j}=f\left(\phi_{i j}, X_{i j}\right)+\varepsilon_{i j} \quad i=1, \ldots, M \quad \mathrm{j}=1, \ldots, n_{i}$

where $f$ is a nonlinear function of the parameter vector $\phi_{i j}$, a composite parameter vector incorporating both fixed and random effects, and the predictor vector $x_{i j}, M$ is the number of species, $n_{i}$ the number of trees within a species, $Y_{i j}$ the response vector or tree component biomass vector for the $n_{i}$ trees in the $i$ th species, and $\varepsilon_{i j}$ the vector of multivariate normally distributed errors in species $i . \phi_{i j}$ is modelled as:

$\phi_{i j}=A i j \times \beta+B_{i j} \times \delta_{i}$

where $\beta$ is the vector of fixed-effects parameters, $\delta_{i}$ the vector of random-effects parameters for species $i, A_{i j}$ and $B_{i j}$ are design matrices of known constants for combining the fixed and random effects of species $i$.

Biomass models were fitted using allometric equations, a specific form of nonlinear equations, expressed as:
$Y=\beta_{0} \times X^{\beta_{1}}+\varepsilon$

Therefore, the general form of allometric mixed-effects model is expressed as:

$Y=\left(\beta_{0}+\delta_{0 i}\right) \times X^{\left(\beta_{1}+\delta_{1 i}\right)}+\varepsilon=\phi_{0 i} \times X^{\phi_{1 \mathrm{i}}}+\varepsilon$

where $\beta_{0}$ is the fixed scaling coefficient, $\delta_{0 \mathrm{i}}$ the random scaling coefficient for species $i, \beta_{1}$ the fixed scaling exponent, $\delta_{1 \mathrm{i}}$ the random scaling exponent for species $i, \phi_{0 \mathrm{i}}$ the composite scaling coefficient $\left(\beta_{0}+\delta_{0 \mathrm{i}}\right.$, fixed + random scaling coefficient) for species $i, \phi_{1 \mathrm{i}}$ the composite scaling exponent $\left(\beta_{1}+\delta_{1 \mathrm{i}}\right.$, fixed + random scaling exponent) for species $i$.

The relation between response variable, the tree component biomass, and the predictors DBH and height were described by the widely used allometric biomass functions (Zianis et al. 2005; Cienciala et al. 2006; Vejpustková et al. 2015), as follows:

$Y=\left(\beta_{0}+\delta_{0 i}\right) \times D^{\left(\beta_{1}+\delta_{1 i}\right)}+\varepsilon=\phi_{0 \mathrm{i}} \times D^{\phi_{\mathrm{li}}}+\eta$

$Y=\left(\beta_{0}+\delta_{0 i}\right) \times D^{\left(\beta_{1}+\delta_{1 i}\right)} \times H^{\left(\beta_{2}+\delta_{2 i}\right)}+\varepsilon=\phi_{0 i} \times D^{\phi_{1 i}} \times H^{\phi_{2 i}}+\varepsilon$

$Y=\left(\beta_{0}+\delta_{0 i}\right) \times\left(D^{2} H\right)^{\left(\beta_{1}+\delta_{1 i}\right)}+\varepsilon=\phi_{0 \mathrm{i}} \times\left(D^{2} H\right)^{\phi_{\mathrm{li}}}+\varepsilon$

Additionally, a model form using the root collar diameter (RCD) only as a predictor was considered to allow the estimate of harvested biomass, as after harvesting the stump dimensions are still available.

$Y=\left(\beta_{0}+\delta_{0 i}\right) \times \mathrm{RCD}^{\left(\beta_{1}+\delta_{1 \mathrm{ii}}\right)}+\varepsilon=\phi_{0 \mathrm{i}} \times \mathrm{RCD}^{\phi_{1 i}}+\varepsilon$

Allometric models are often fitted to logarithmically transformed data (Overman et al. 1994; Bervian et al. 2006; Cienciala et al. 2006; Blujdea et al. 2012; Makungwa et al. 2013; Paul et al. 2013a, b, 2019; Vahedi et al. 2014; Annighöfer et al. 2016; Goussanou et al. 2016; Chen et al. 2017) to deal with heteroskedasticity, where the standard errors of a variable, over a specific time, are non-constant (Overman et al. 1994; Blujdea et al. 2012; Zapata-Cuartas et al. 2012; Vahedi et al. 2014; Goussanou et al. 2016). They facilitate model fitting by transforming the equation to a linear form (Overman et al. 1994; Blujdea et al. 2012; Zapata-Cuartas et al. 2012; Goussanou et al. 2016), allowing the use of linear least squares. In this study, logarithmic transformation of the data was avoided because the results of standard statistical tests performed on such data are often not relevant (Feng et al. 2014). Log-transformation leads to biased results (Packard and Boardman 2008). Traditional allometric method, which consists of linear fitting to logarithmically transformed data and back-transformation to power-law form, is not well suited for fitting statistical 
models to data expressed in the arithmetic scale (Packard 2013). Castro et al. (1996) maintained that modelling raw un-transformed data gives the best results.

To address within-species heteroskedasticity, the models in Eqs. 5-8 were, instead of being log-transformed, fitted using weighted NLME models. This is justified because, quite often in regression, the error variance is functionally related to the predictors (Parresol 1999), i.e., the variability of the biomass increases with the predictors (Picard 2012).

The weight functions that describe the within-species heteroskedasticity structure were obtained by modelling the error structure of ordinary least squares (OLS), following the description by Parresol $(1999,2001)$. The squares of OLS residuals were fitted against the different combination of the predictors and it was assumed that the squares are representative of the error variance (Parresol 2001). NLME models were fitted using the NLME package (Pinheiro et al. 2019) of R software (R Core Team 2020).

Various authors have suggested that tree biomass scales against stem diameter with a universal scaling exponent of 8/3 (West et al. 1999; Enquist 2002; Pilli et al. 2006). However, several researchers have noted a lack of agreement between the scaling exponent in allometric equations and the universal scaling exponent (Chambers et al. 2001; Zianis and Mencuccini 2004; Li et al. 2005; Návar 2009). Other researchers have stressed that the universal scaling exponent is not acceptable, since the ratio of aboveground biomass to diameters in different environmental conditions is not constant (Zianis and Mencuccini 2004; Niklas 2006), and because there is a large variability in allometry across species (Zapata-Cuartas et al. 2012). Therefore, to test the allometric universal scaling law, Eq. 5 was refitted for all tree components with the scaling exponent set to 8/3. Predicted biomass values from Eq. 5 fitted without and with limitations on the scaling exponent and the observed biomass were compared using one-way ANOVA. Pairwise comparisons among biomass means were tested using Tukey HSD test.

When fitting the models, parameters, either fixed or random, with estimates not significantly different from zero at $\alpha=0.05$ were removed, and the reduced model refitted. This procedure was continued until only parameters with statistically significant estimates remained.

Tree component BCEFs were computed as the ratio of tree component biomass and stem volume (Magalhães and Mate 2018). A three-way ANOVA was carried out to test for the effects of species, DBH and total height on BCEF. Tukey HSD test was used to find species-level BCEFs statistically different from each other.

Communality analysis was carried out to quantify the variance that was unique to each predictor and the variance that was common to groups of predictors, thereby identifying which predictor accounted the most to the variability of BCEF. Commonality analysis was performed using "yhat" package (Nimon et al. 2015). The dependence of BCEF on DBH and height was analysed by testing the significance of the Pearson's correlation coefficient.

All statistical analyses were performed at a 5\% significance level.

\section{Model evaluation and validation}

Predictive accuracy determined which model(s) described the relationship between component biomass and the most used dendrometric predictors better, based on the following goodness of fit statistics: Akaike's Information Criterion, AIC, (Akaike 1973), mean residual $\overline{\mathrm{E}}$, (von Gadow and Hui 1999), model precision V (Calama and Montero 2004; Correia et al. 2010a), Furnival's index of fit, FI (Furnival 1961), and the root mean square error, RMSE (von Gadow and Hui 1999), Eqs. 9-13, respectively:

$A I C_{i}=-2 \log L_{i}+2 P_{i}$

$\bar{E}_{i}=\frac{\sum\left(Y_{i}-\hat{Y}_{i}\right)}{n}=\frac{\sum \varepsilon_{i j}^{2}}{n}$

$V_{i}=\frac{\sum \varepsilon_{i j}^{2}-\left(\sum \varepsilon_{i j}\right)^{2} / n}{(n-1) n}$

$F I_{i}=[f(Y)]^{-1} \times \sqrt{M S E_{i}}$

$\operatorname{RMSE}_{i}=\sqrt{\frac{\sum\left(Y_{i}-\hat{Y}_{i}\right)^{2}}{n-1-P_{i}}}$

where $L_{i}$ is the maximum likelihood of the $i$ th model, $\mathrm{P}_{\mathrm{i}}$ the number of parameters of the $i$ th model, $Y_{i}$ observed biomass, $\hat{Y}_{i}$ predicted biomass of the $i$ th model, $\varepsilon_{i j}$ residual from the biomass of the $j$ th tree of the $i$ th model, $f^{\prime}(Y)$ is the first derivative of the transformed response variable, and $\mathrm{MSE}_{\mathrm{i}}$ the mean square error of the $i$ th model. Square brackets indicate the geometric mean.

For ease of comparison between models, $\overline{\mathrm{E}}, \mathrm{V}$, and RMSE were expressed as relative values, a percentage of observed biomass $\mathrm{Y}$, which is more revealing. Model precision (V) was expressed as the standard error of the residuals.

The ideal value of $\overline{\mathrm{E}}, \mathrm{V}$, and RMSE is zero (von Gadow and Hui 1999), indicating a perfect fit. Lower values of AIC and FI indicate a better fit model (Furnival 1961; Akaike 1973). Therefore, models with the lowest AIC, FI, $\overline{\mathrm{E}}, \mathrm{V}$, and RMSE were judged the best.

The coefficient of determination $\left(\mathrm{R}^{2}\right)$ was not used to evaluate the performance of the models because it is inappropriate for demonstrating the performance or validity of 
nonlinear models (Spiess and Neumeyer 2010; Magalhães and Mate 2018). This is because the regression sum-ofsquares and the residual sum-of-squares do not total the sum-of-squares as in linear least squares, and thus $\mathrm{R}^{2}$ is no longer between 0 and 100\% (Magalhães and Mate 2018).

To evaluate the predictive ability, the models were validated using an independent dataset. The following statistics were used: model efficiency or EF, (Soares et al. 1995; Vanclay and Skovsgaard 1997) and Error (Calama and Montero 2004), Eqs. 14 and 15. Additionally, observed and predicted biomasses were compared using the Wilcoxon signed rank test.

$\mathrm{EF}=1-\frac{\sum\left(Y_{i}-\bar{Y}_{i}\right)^{2}}{\sum\left(Y_{i}-\bar{Y}_{i}\right)^{2}}$

Error $=\sum\left(Y_{i}-\bar{Y}_{i}\right)$

$\mathrm{EF}$ was expressed as a percentage. The ideal values of EF and Error are 100\% and 0\%, respectively, indicating perfect predictive ability. Therefore, models with the largest EF, the smallest Error, and no significant difference between observed and predicted biomass, as judged by the Wilcoxon test, were considered the best.

The independent dataset used for validation consisted of data from 81 trees: 12 B. spiciformis (DBH 5.1-34.0 cm), 8 J. globiflora (DBH 5.0-29.3 cm), 6 E. cloeziana (DBH 23.0-39.0 cm), 28 P. taeda (DBH 9.5-38.5 cm), 10 P. elliotti (DBH 9.8-25.5 cm), and 17 P. patula (DBH $14.5-28.5 \mathrm{~cm}$ ). Of these sampled trees, 59 were collected in 2017 (Guedes et al. 2018) and the remaining collected between 2014 and 2018 for various unpublished research.

\section{Results}

\section{Measured data}

Component biomass plotted against DBH, stratified by species, strongly followed a power relationship for all components (Fig. 1). Tree species revealed a differing set of trees, especially for crown biomass. The power trend was strong for stems and AGB but the scatter was larger for crowns, especially for larger DBH trees. The ratio of stem biomass to AGB was larger for exotic species than for indigenous species, and amounted to $94 \%, 81 \%, 77 \%$, and $71 \%$ for $E$. cloeziana, P. patula, P. taeda, and P. elliotti, respectively (Fig. 2). For the Miombo species, the largest ratio was crown biomass to AGB, and amounted to 55\% and 54\% for B. spiciformis and J. globiflora, respectively (Fig. 2).
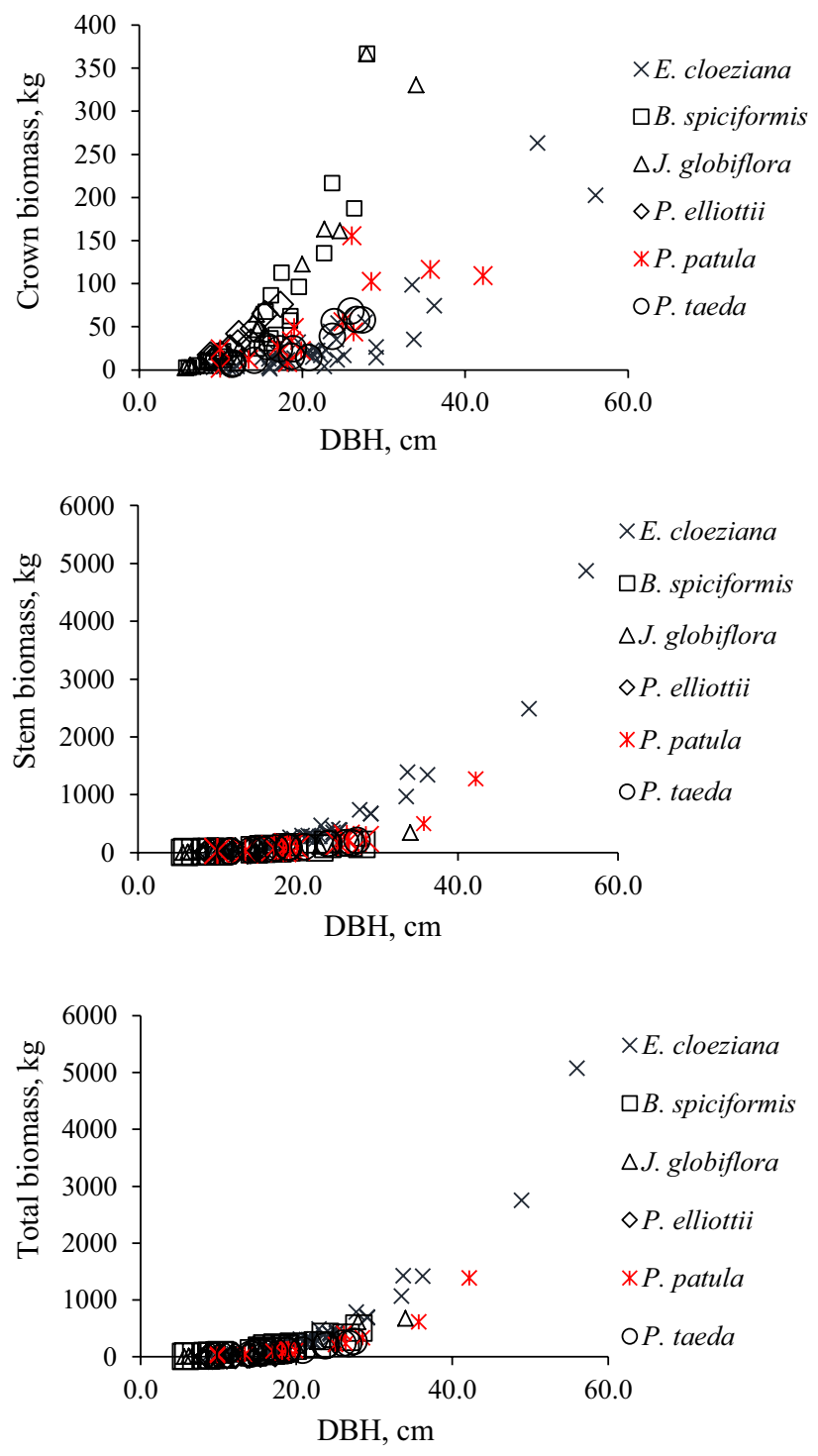

Fig. 1 Biomass plotted against diameter at breast height

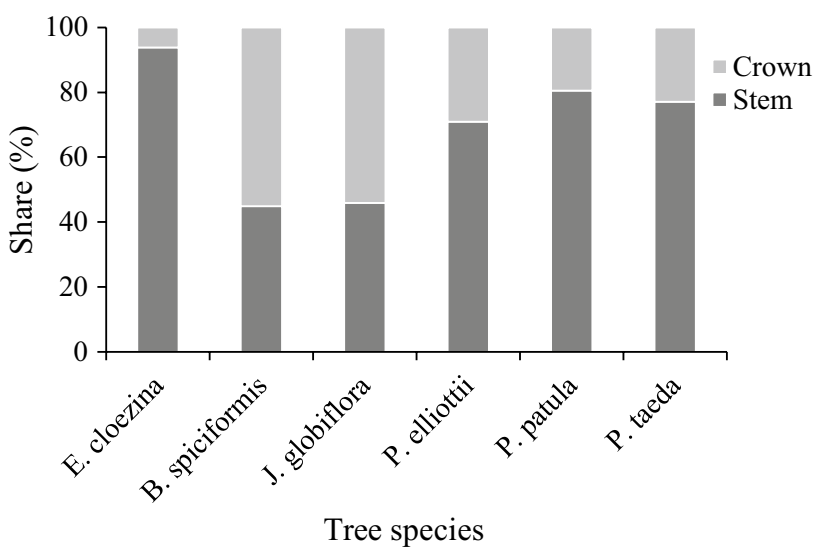

Fig. 2 Component biomass partitioning for different exotic and indigenous species 
The share of component biomass on total aboveground biomass showed a species-specific pattern (Fig. 3). For all exotic species except for Pinus patula, the percentage of stem and crown biomass was stable over the DBH range. The percentage of stem biomass of $P$. patula increased slightly with diameter and a slight decrease was found for crown biomass. For the Miombo species, while the percentage of stem biomass decreased steeply with DBH, there was a steep increase for the percentage of crown biomass with DBH. For B. spiciformis, the portion of stem biomass to AGB decreased with DBH from approximately $90 \%$ to $30 \%$ and that of the crown increased from 14 to $73 \%$. Similar results were observed for J. globiflora, with the percentage of stem biomass decreasing with DBH from 87 to $8 \%$ and the crown increasing from 13 to $92 \%$.
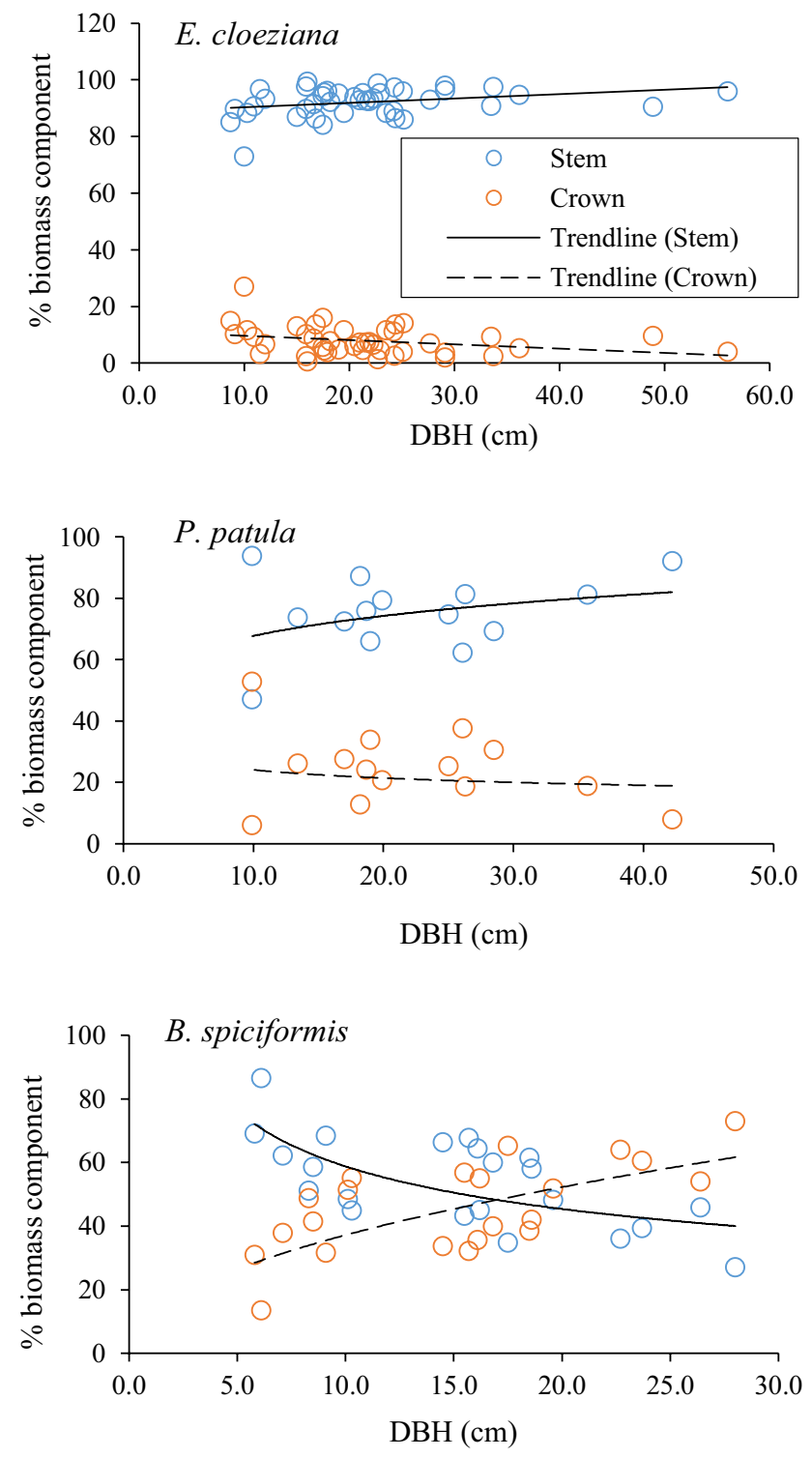

\section{Biomass allometry}

Species-specific allometric biomass models with DBH, $\mathrm{RCD}$ (root collar diameter), and height $(\mathrm{H})$ as predictors and component biomass as response variables were constructed. The weight functions and the random scaling coefficients and exponents of the models were influenced by species-specific factors and by biomass components. All fixed scaling exponents and fixed and random scaling coefficients were significant at $\alpha=0.05$ (Tables 2, 3, 4 and 5). However, the random scaling exponents were significant only for crown biomass models (Tables 2, 3, 4 and 5). All biomass allometric models had an acceptable predictive accuracy and ability (Table 6). However, stem and AGB allometric models fitted the data better than crown
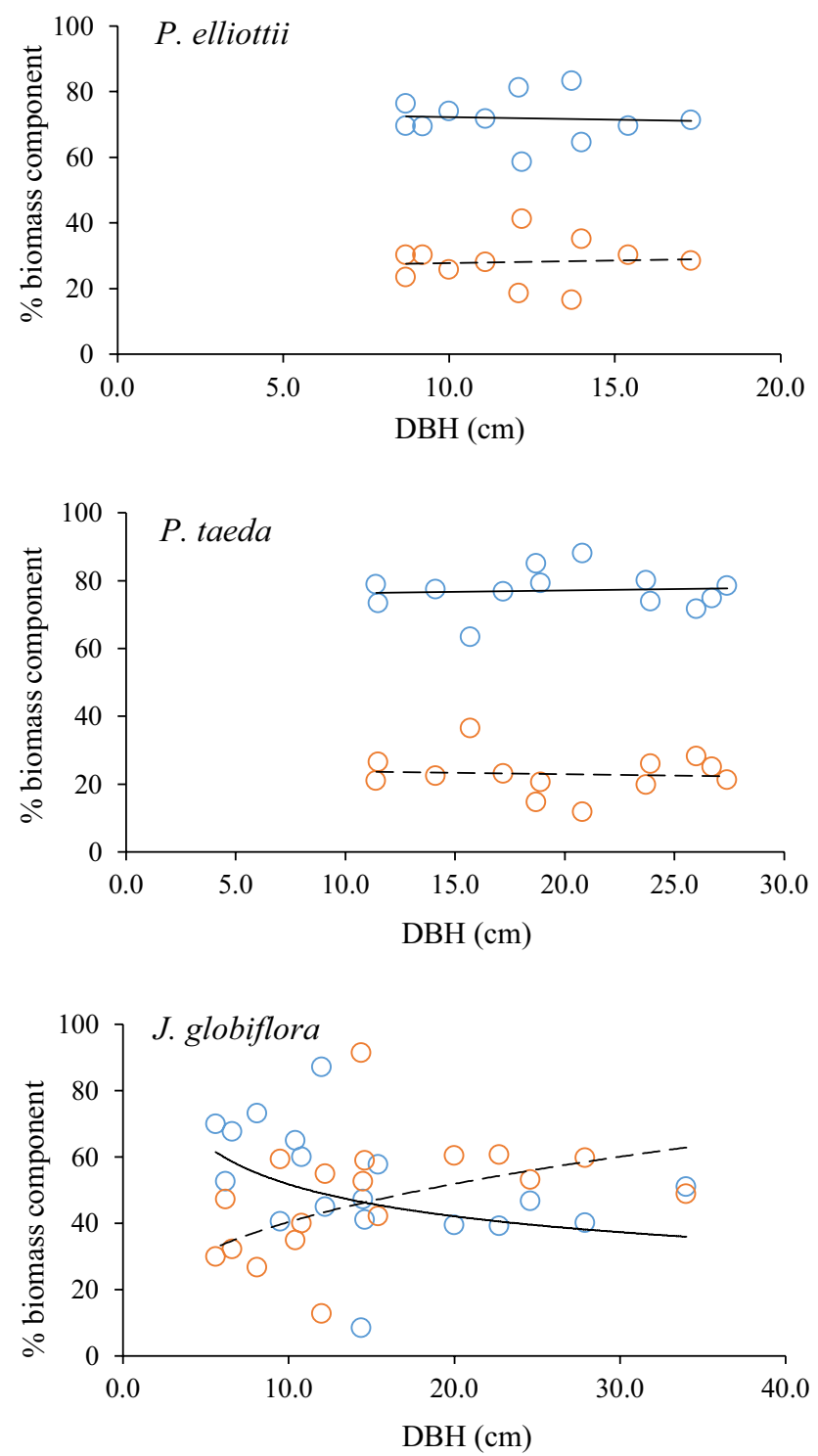

Fig. 3 Pattern of biomass components on AGB as governed by diameter at breast height 
Table 2 Parameter estimates of the models for stem biomass

\begin{tabular}{lllll}
\hline Parameter & Equation 5 & Equation 6 & Equation 7 & Equation 8 \\
\hline Weight function & $\exp \left(\mathrm{D}^{0.5250}\right)$ & $\exp \left(\mathrm{D}^{0.8257}\right)$ & $0.6818 \times \mathrm{D}^{2.8479}$ & $\exp \left(\left(\mathrm{D}^{2} \mathrm{H}\right)^{0.0821}\right)$ \\
$\beta_{0}( \pm \mathrm{SE})$ & $0.0209( \pm 0.0049)$ & $0.0184( \pm 0.0032)$ & $0.0186( \pm 0.0028)$ & $0.0057( \pm 0.0017)$ \\
$\beta_{1}( \pm \mathrm{SE})$ & $2.8929( \pm 0.0576)$ & $2.0708( \pm 0.1103)$ & $1.0060( \pm 0.0137)$ & $3.0735( \pm 0.0669)$ \\
$\beta_{2}( \pm \mathrm{SE})$ & - & $0.9386( \pm 0.1150)$ & - & - \\
$\delta_{0 \text { B. spiciformis }}$ & -0.0032 & 0.0040 & 0.0046 & -0.0017 \\
$\delta_{0 \text { E. cloeziana }}$ & 0.0178 & 0.0029 & 0.0018 & 0.0062 \\
$\delta_{0 \text { J. globiflora }}$ & -0.0037 & 0.0040 & 0.0047 & -0.0019 \\
$\delta_{0 \text { P. elliotti }}$ & -0.0042 & -0.0032 & -0.0033 & -0.0014 \\
$\delta_{0 \text { P. patula }}$ & -0.0027 & -0.0039 & -0.0034 & -0.0007 \\
$\delta_{0 \text { P. taeda }}$ & -0.0040 & -0.0038 & -0.0044 & -0.0005 \\
$\mathrm{~s}\left(\delta_{0}\right)$ & 0.0081 & 0.0038 & 0.0040 & 0.0029 \\
$\mathrm{~s}(\mathrm{e})$ & 0.2240 & 0.9536 & 0.0492 & 0.0038 \\
$\phi_{0 \text { B. spiciformis }}$ & 0.0178 & 0.0224 & 0.0232 & 0.0040 \\
$\phi_{0 \text { E. cloeziana }}$ & 0.0387 & 0.0213 & 0.0204 & 0.0119 \\
$\phi_{0 \text { J. globifora }}$ & 0.0172 & 0.0224 & 0.0233 & 0.0038 \\
$\phi_{0 \text { P. elliotti }}$ & 0.0167 & 0.0151 & 0.0153 & 0.0043 \\
$\phi_{0 \text { P. patula }}$ & 0.0182 & 0.0145 & 0.0152 & 0.0050 \\
$\phi_{0 \text { P. taeda }}$ & 0.0170 & 0.0146 & 0.0142 & 0.0052 \\
\hline
\end{tabular}

where $\delta_{0 \mathrm{i}}$ is the random scaling coefficient of the species i, (e.g., $\delta_{0 \text { B spiciformis }}$ random scaling coefficient for Brachystegia spiciformis), $\mathrm{s}\left(\mathrm{\delta}_{0}\right)$ standard deviation of the random scaling coefficients, $\mathrm{s}(\mathrm{e})$ standard deviation of the residuals, $\phi_{0 \mathrm{i}}$ composite scaling coefficient of the species i. Non-significant random parameters are not presented models as indicated by the AIC, V, E, FI, and RMSE values (Table 6).

Using only DBH as a predictor, the models estimated tree component biomass with a satisfactory predictive accuracy, i.e., model precision $(\mathrm{V})<2 \%$ and mean residual $(\mathrm{E})$ not statistically different from zero, and predictive ability, model efficiency $(\mathrm{EF})>72 \%$ and Wilcoxon test revealing that observed and predicted biomass were statistically identical. Adding height as an incorporated variable $\left(D^{2} \mathrm{H}\right)$ or as a second variable improved the predictive accuracy and ability, however better prediction was observed when height was added as a second variable (Eq. 6, $\left.Y=\phi_{0 i} \times D^{\phi_{1 i}} \times H^{\phi_{2 i}}+\varepsilon\right)$. Adding height as an incorporated variable $\left(\mathrm{D}^{2} \mathrm{H}\right), \mathrm{AIC}$, model precision $\mathrm{V}$, and the root mean square error, RMSE, decreased up to $5 \%, 23 \%$, and $26 \%$, respectively, and the EF increased up to $15 \%$. However, adding height as a second variable, the AIC, V, and RMSE decreased up to $10 \%, 28 \%$, and $50 \%$, respectively, and EF increased up to $28 \%$. The allometric biomass model including height as the second predictor (Eq. 6) was the best for all components.

Satisfactory predictive accuracy and predictive ability were also attained for the models using only root collar diameter (RCD), however the models were not better as those with only DBH as a predictor (Table 6). The models fitted using the universal scaling exponent $\left(\mathrm{D}^{8 / 3}\right)$ were better than the RCD models and fitted the data similarly as the DBH models. Figure 4 shows clearly that the measured biomass, the predicted biomass from Eq. 5, and the predicted biomass using the universal scaling exponent did not differ statistically.

Using the interactive $\mathrm{D}^{2} \mathrm{H}$ as a predictor, an isometric scaling $\left(b_{1}=1\right)$ was obtained for all tree components, implying that, for the $\mathrm{DBH}$ range considered in this study, the ratio of biomass and $\mathrm{D}^{2} \mathrm{H}$ was constant. A positive allometry was found when $\mathrm{DBH}$ or RCD were used as the sole predictor. A fixed scaling exponent $\left(b_{1}\right)$ of $\approx 3$ (range: 2.89-3.07) was found when RCD was used as the predictor. Using only $\mathrm{DBH}$ as a predictor, the fixed scaling exponent $\left(b_{1}\right)$ ranged from 2.60 to 2.89 . These fixed scaling exponents, obtained when biomass is scaled against DBH only, were not statistically different to the universal scaling exponent (8/3) proposed by West et al. (1999).

Crown models using only DBH as a predictor for the Miombo species had larger scaling exponents (up to 25\%) than those for exotic species. The larger values for the indigenous species imply that, per unit of DBH growth, the increment of crown biomass is larger, up to $25 \%$, compared with exotic species. Note that, for stem biomass and AGB models, the random scaling exponents were not statistically different from zero, thus the composite scaling exponents were equal to the fixed ones, denoting that a unit of DBH increase resulted in similar stem and aboveground biomass increment for all species. 
Table 3 Parameter estimates of the models for crown biomass

\begin{tabular}{|c|c|c|c|c|}
\hline Parameter & Equation 5 & Equation 6 & Equation 7 & Equation 8 \\
\hline Weight function & $53.0000 \times \mathrm{D}^{41.4121}$ & $\exp \left(D^{0.1212}\right)$ & $\exp \left(D^{1.3793}\right)$ & $37.0800 \times \mathrm{D}^{28.5197}$ \\
\hline$\beta_{0}( \pm \mathrm{SE})$ & $0.0186( \pm 0.0047)$ & $0.0256( \pm 0.0074)$ & $0.0080( \pm 0.0033)$ & $0.0029( \pm 0.0012)$ \\
\hline$\beta_{1}( \pm \mathrm{SE})$ & $2.5969( \pm 0.1254)$ & $3.1152( \pm 0.1509)$ & $0.9657( \pm 0.0680)$ & $2.9707( \pm 0.1435)$ \\
\hline$\beta_{2}( \pm \mathrm{SE})$ & - & $-0.6760( \pm 0.2050)$ & - & - \\
\hline$\delta_{1 \text { B. spiciformis }}$ & 0.2828 & - & 0.1441 & 0.2504 \\
\hline$\delta_{1 \text { E. cloeziana }}$ & -0.2751 & - & -0.1623 & -0.2276 \\
\hline$\delta_{1 \text { J. globiflora }}$ & 0.2823 & - & 0.1579 & 0.2188 \\
\hline$\delta_{1 \text { P. elliotti }}$ & -0.0924 & - & -0.0304 & -0.0489 \\
\hline$\delta_{1 \text { P.patula }}$ & -0.0650 & - & -0.0426 & -0.1143 \\
\hline$\delta_{1 P . \text { taeda }}$ & -0.1326 & - & -0.0667 & -0.0784 \\
\hline$\delta_{2 \text { B. spiciformis }}$ & - & 0.2210 & - & - \\
\hline$\delta_{2 \text { E. cloeziana }}$ & - & -0.1558 & - & - \\
\hline$\delta_{2 \text { J. globiflora }}$ & - & 0.2147 & - & - \\
\hline$\delta_{2}$ P. elliotti & - & -0.1066 & - & - \\
\hline$\delta_{2 \text { P. patula }}$ & - & -0.0442 & - & - \\
\hline$\delta_{2 P . t a e d a}$ & - & -0.1291 & - & - \\
\hline $\mathrm{s}\left(\delta_{1}\right)$ & 0.2166 & - & 0.1166 & 0.1840 \\
\hline $\mathrm{s}\left(\delta_{2}\right)$ & - & 0.1658 & - & - \\
\hline $\mathrm{s}(\mathrm{e})$ & 0.0274 & $2.50 \times 10^{-07}$ & 4.2769 & 0.0892 \\
\hline$\phi_{1 \text { B. spiciformis }}$ & 2.8796 & - & 1.1398 & 3.2211 \\
\hline$\phi_{1 \text { E. cloeziana }}$ & 2.3218 & - & 0.8334 & 2.7431 \\
\hline$\phi_{1 \text { J. globiflora }}$ & 2.8792 & - & 1.1536 & 3.1895 \\
\hline$\phi_{1 \text { P. elliotti }}$ & 2.5045 & - & 0.9653 & 2.9218 \\
\hline$\phi_{1 \text { P. patula }}$ & 2.5319 & - & 0.9530 & 2.8564 \\
\hline$\phi_{1 \text { P. taeda }}$ & 2.4643 & - & 0.9290 & 2.8923 \\
\hline$\Phi_{2 \text { B. spiciformis }}$ & - & -0.4549 & - & - \\
\hline$\phi_{2 \text { E. cloeziana }}$ & - & -0.8318 & - & - \\
\hline$\Phi_{2 \text { J. globiflora }}$ & - & -0.4612 & - & - \\
\hline$\phi_{2}$ P. elliotti & - & -0.7825 & - & - \\
\hline$\Phi_{2 \text { P. patula }}$ & - & -0.7201 & - & - \\
\hline$\phi_{2 P . t a e d a}$ & - & -0.8051 & - & - \\
\hline
\end{tabular}

where $\delta_{1 \mathrm{i}}$ and $\delta_{2 \mathrm{i}}$ are the random scaling exponents of the species i, (e.g., $\delta_{1 \text { B. Spiciformis }}$ random scaling exponent for Brachystegia spiciformis), s $\left(\delta_{1}\right)$ standard deviation of the random scaling exponents $\delta_{1}$, and s $\left(\delta_{2}\right)$ standard deviation of the random scaling exponents $\delta_{2}$. Non-significant random parameters are not presented

\section{Biomass conversion and expansion factors (BCEF)}

Biomass conversion and expansion factors (BCEF) are widely used to convert timber volume of forest inventories to tree biomass, and are calculated as the ratio of component biomass to stem volume. Aboveground biomass of $B$. spiciformis and J. globiflora were approximately $157 \%$ and $139 \%$ of the stem volume (Table 7), respectively; however, the AGB of the exotic species were only up to $69 \%$ of stem volume. This suggests that Miombo species store more than double the aboveground biomass per stem volume, i.e., the BCEF are more than double that of the exotic species. Miombo species store up to 13 times more biomass in the crown per stem volume than the introduced species.
The three-way ANOVA revealed that, for all three components, stem, crown, and shoot system, the species was a significant source of variation of the BCEF $(P$ value $=0.0000)$. In addition to species, DBH and height also had significant effects on crown BCEF; height was also a significant source of aboveground BCEF variation. Tukey HSD test showed that BCEF values of the two Miombo species were statistically superior to those of all introduced species (Table 7).

From the commonality analysis, the majority (60-99\%) of the regression effect was explained by variance that was unique to a species, i.e., species uniquely accounted for up to $99 \%$ of the regression effect. Tree species accounted for $59.5 \%, 62.5 \%$, and $99 \%$ of the regression effect of crown, aboveground, and stem BCEF, respectively. 
Table 4 Parameter estimates of the models for aboveground biomass

\begin{tabular}{lllll}
\hline Parameter & Equation 5 & Equation 6 & Equation 7 & Equation 8 \\
\hline Weight function & $\exp \left(\mathrm{D}^{0.1190}\right)$ & $8.0189 \times \mathrm{D}^{22.2793}$ & $26.2926 \times \mathrm{D}^{30.9585}$ & $35.4436 \times \mathrm{D}^{22.5197}$ \\
$\beta_{0}( \pm \mathrm{SE})$ & $0.0414( \pm 0.0068)$ & $0.0334( \pm 0.0058)$ & $0.0302( \pm 0.0065)$ & $0.0086( \pm 0.0019)$ \\
$\beta_{1}( \pm \mathrm{SE})$ & $2.7921( \pm 0.0431)$ & $2.3767( \pm 0.0923)$ & $1.0012( \pm 0.0143)$ & $3.0614( \pm 0.0573)$ \\
$\beta_{2}( \pm \mathrm{SE})$ & - & $0.5420( \pm 0.1096)$ & - & - \\
$\delta_{0 \text { B. spiciformis }}$ & 0.0063 & 0.0131 & 0.0178 & 0.0003 \\
$\delta_{0 \text { E. cloeziana }}$ & 0.0158 & 0.0005 & -0.0073 & 0.0047 \\
$\delta_{0 \text { J. globifora }}$ & 0.0062 & 0.0139 & 0.0189 & -0.0003 \\
$\delta_{0 \text { P. elliotti }}$ & -0.0102 & -0.0087 & -0.0087 & -0.0017 \\
$\delta_{0 \text { P. patula }}$ & -0.0067 & -0.0080 & -0.0094 & -0.0016 \\
$\delta_{0 \text { P. taeda }}$ & -0.0113 & -0.0109 & -0.0113 & -0.0013 \\
$\mathrm{~s}\left(\delta_{0}\right)$ & 0.0103 & 0.0104 & 0.0131 & 0.0023 \\
$\mathrm{~s}(\mathrm{e})$ & $4.42 \times 10^{-08}$ & 0.0307 & 0.0296 & 2.1158 \\
$\phi_{0 \text { B. spiciformis }}$ & 0.0477 & 0.0465 & 0.0480 & 0.0089 \\
$\phi_{0 \text { E. cloeziana }}$ & 0.0572 & 0.0339 & 0.0229 & 0.0133 \\
$\phi_{0 \text { J. globiflora }}$ & 0.0476 & 0.0473 & 0.0491 & 0.0084 \\
$\phi_{0 \text { P. elliotti }}$ & 0.0312 & 0.0247 & 0.0215 & 0.0069 \\
$\phi_{0 \text { P. patula }}$ & 0.0346 & 0.0254 & 0.0208 & 0.0070 \\
$\phi_{0 \text { P. taeda }}$ & 0.0300 & 0.0225 & 0.0189 & 0.0074 \\
\hline
\end{tabular}

Non-significant random parameters are not presented

\begin{tabular}{llll}
\hline Parameter & Equation 5 (Stem) & Equation 5 (Crown) & Equation 5 (AGB) \\
\hline Weight function & $\exp \left(\mathrm{D}^{0.5250}\right)$ & $53.0000 \times \mathrm{D}^{41.4121}$ & $\exp \left(\mathrm{D}^{0.1190}\right)$ \\
$\beta_{0}( \pm \mathrm{SE})$ & $0.0407( \pm 0.0067)$ & $0.0172( \pm 0.0072)$ & $0.0596( \pm 0.0063)$ \\
$\beta_{1}( \pm \mathrm{SE})$ & 2.6667 & 2.6667 & 2.6667 \\
$\delta_{0 \text { B. spiciformis }}$ & -0.0057 & 0.0172 & 0.0088 \\
$\delta_{0 \text { E. cloeziana }}$ & 0.0348 & -0.0112 & 0.0231 \\
$\delta_{0 \text { J. globiflora }}$ & -0.0070 & 0.0174 & 0.0084 \\
$\delta_{0 \text { P. elliotti }}$ & -0.0108 & -0.0060 & -0.0168 \\
$\delta_{0 \text { P. patula }}$ & -0.0042 & -0.0062 & -0.0080 \\
$\delta_{0 \text { P. taeda }}$ & -0.0071 & -0.0060 & -0.0156 \\
$\mathrm{~s}\left(\delta_{0}\right)$ & 0.0160 & 0.0124 & 0.0149 \\
S(e) & 0.1675 & 0.0379 & $1.26 \times 10^{-08}$ \\
$\phi_{0 \text { B. spiciformis }}$ & 0.0350 & 0.0344 & 0.0684 \\
$\phi_{0 \text { E. cloeziana }}$ & 0.0755 & 0.0060 & 0.0827 \\
$\phi_{0 \text { J. globiflora }}$ & 0.0338 & 0.0346 & 0.0679 \\
$\phi_{0 \text { P. elliotti }}$ & 0.0299 & 0.0112 & 0.0428 \\
$\Phi_{0 \text { P. patula }}$ & 0.0365 & 0.0110 & 0.0516 \\
$\Phi_{0 \text { P. taeda }}$ & 0.0336 & 0.0112 & 0.0440 \\
\hline & & &
\end{tabular}

Table 5 Parameter estimates of Eq. 5 fitted using universal scaling exponent
Tree component BCEF of all exotic or introduced species, and stem and aboveground BCEF of Miombo species were not linearly correlated to DBH nor to height $(P$ value $>0.2$ ). Crown BCEF of Miombo species was positively dependent on both DBH and height (Fig. 5), and Pearson's correlation coefficients between crown BCEF and DBH and height were $0.55(P$ value $=0.0002)$, and $0.33(P$ value $=0.0349)$, respectively.

\section{Discussion}

\section{Biomass allocation patterns}

Studies on biomass allocation patterns into different tree components are of considerable interest in forest carbon monitoring and dynamics (Fournier et al. 2003; Pajtík et al. 2008; Magalhães and Seifert 2015b). For example, with the 
Table 6 Predictive accuracy and ability of the fitted models

\begin{tabular}{|c|c|c|c|c|c|}
\hline \multirow[t]{2}{*}{ Parameter } & \multicolumn{5}{|c|}{ Species-specific models } \\
\hline & Equation 5 & Equation 6 & Equation 7 & Equation 8 & $\begin{array}{l}\text { Equation } 5 \\
\text { (universal) }\end{array}$ \\
\hline \multicolumn{6}{|l|}{ Stem biomass } \\
\hline \multicolumn{6}{|c|}{ Goodness of fit statistics (predictive accuracy) } \\
\hline AIC & 1047 & 943 & 994 & 1047 & 1052 \\
\hline $\mathrm{E}(\%)$ & $0.0898^{\mathrm{ns}}$ & $1.0097^{\mathrm{ns}}$ & $0.3460^{\mathrm{ns}}$ & $3.0482^{\mathrm{ns}}$ & $9.4382^{\mathrm{ns}}$ \\
\hline $\mathrm{V}(\%)$ & 1.3456 & 1.1170 & 1.2391 & 1.3048 & 1.5134 \\
\hline FI & 594 & 579 & 642 & 680 & 730 \\
\hline RMSE (\%) & 12.6579 & 6.2695 & 12.1670 & 14.4946 & 13.11848 \\
\hline \multicolumn{6}{|l|}{ Validation (predictive ability) } \\
\hline $\mathrm{EF}(\%)$ & 76.52 & 94.37 & 84.90 & 79.15 & 76.45 \\
\hline Error $(\mathrm{kg})$ & 1.7774 & 0.1649 & 0.8897 & 5.7630 & 1.9117 \\
\hline$P$ value for Wilcoxon test & 0.1660 & 0.9549 & 0.9970 & 0.1445 & 0.2466 \\
\hline \multicolumn{6}{|l|}{ Crown biomass } \\
\hline \multicolumn{6}{|c|}{ Goodness of fit statistics (predictive accuracy) } \\
\hline AIC & 1111 & 1004 & 1058 & 1168 & 1120 \\
\hline $\mathrm{E}(\%)$ & $-0.3920^{\mathrm{ns}}$ & $-0.5782^{\mathrm{ns}}$ & $-0.2457^{\mathrm{ns}}$ & $0.7234^{\mathrm{ns}}$ & -0.1960 \\
\hline $\mathrm{V}(\%)$ & 3.4926 & 2.5289 & 2.7304 & 4.7645 & 3.7119 \\
\hline FI & 6973 & 5051 & 5452 & 8508 & 7416 \\
\hline RMSE (\%) & 18.5852 & 12.3457 & 13.6892 & 27.0770 & 23.0200 \\
\hline \multicolumn{6}{|l|}{ Validation (predictive ability) } \\
\hline $\mathrm{EF}(\%)$ & 72.23 & 92.50 & 81.10 & 51.67 & 70.11 \\
\hline Error $(\mathrm{kg})$ & -4.4789 & 1.4786 & 4.0859 & 18.6122 & -4.6953 \\
\hline$P$ value for Wilcoxon test & 0.1085 & 0.4593 & 0.1071 & 0.1465 & 0.0617 \\
\hline \multicolumn{6}{|l|}{ Aboveground biomass } \\
\hline \multicolumn{6}{|c|}{ Goodness of fit statistics (predictive accuracy) } \\
\hline AIC & 1029 & 985 & 1002 & 1050 & 1038 \\
\hline $\mathrm{E}(\%)$ & $1.5513^{\mathrm{ns}}$ & $0.1631^{\mathrm{ns}}$ & $1.2360^{\mathrm{ns}}$ & $3.2019^{\mathrm{ns}}$ & $2.4781^{\mathrm{ns}}$ \\
\hline $\mathrm{V}(\%)$ & 2.7112 & 2.0075 & 2.5134 & 4.2022 & 3.0731 \\
\hline FI & 1056 & 661 & 715 & 1281 & 1103 \\
\hline RMSE (\%) & 15.0298 & 9.5807 & 12.7952 & 17.5641 & 15.8618 \\
\hline \multicolumn{6}{|l|}{ Validation (predictive ability) } \\
\hline $\mathrm{EF}(\%)$ & 76.59 & 94.13 & 88.28 & 81.05 & 76.35 \\
\hline Error (kg) & -0.8198 & 0.9280 & 0.9981 & 5.2396 & -2.9780 \\
\hline$P$ value for Wilcoxon test & 0.1158 & 0.8734 & 0.1307 & 0.0668 & 0.0587 \\
\hline
\end{tabular}

Equation 5 (Universal)=Eq. 5 fitted under the constraint of the scaling exponent being equal to the universal scaling of 8/3; i.e. assuming that tree biomass scales against stem diameter with a universal scaling exponent of $8 / 3$

Miombo woodlands, while the stem or bole is used in the forest industry and thus the $\mathrm{C}$ remains stored for some time, the branches are either left in the forest or collected and used as firewood by local communities. In either case, the stored carbon is released to the atmosphere by decomposition or burning.

The biomass allocation patterns of the exotic species in this study is in agreement with a number of studies (Cienciala et al. 2006; Correia et al. 2010a, b; Xiang et al. 2011; Vargas-Larreta et al. 2017) for Pine and Eucalyptus species; as trees grow larger, the proportion of aboveground biomass allocated to the stem increases and that allocated to the crown decreases, and/or the majority of the AGB is allocated to the stem. However, this pattern of allocation was not supported by the two Miombo species as most of the AGB was allocated to the crown, and the proportion increased with increasing tree size. An increase proportion of branch biomass, and thus crown biomass, has been reported by Pajtík et al. (2008) for Norway spruce (Picea abies (L.) H. Karst.). The proportion of AGB allocated to the stem for the Miombo species in this study, $45 \%$ and $46 \%$ for B. spiciformis and J. globiflora, respectively, is lower 
Fig. 4 Tukey HSD test results showing the similarities between observed biomass, predicted biomass by Eq. 5 , and predicted biomass using the universal scaling exponent

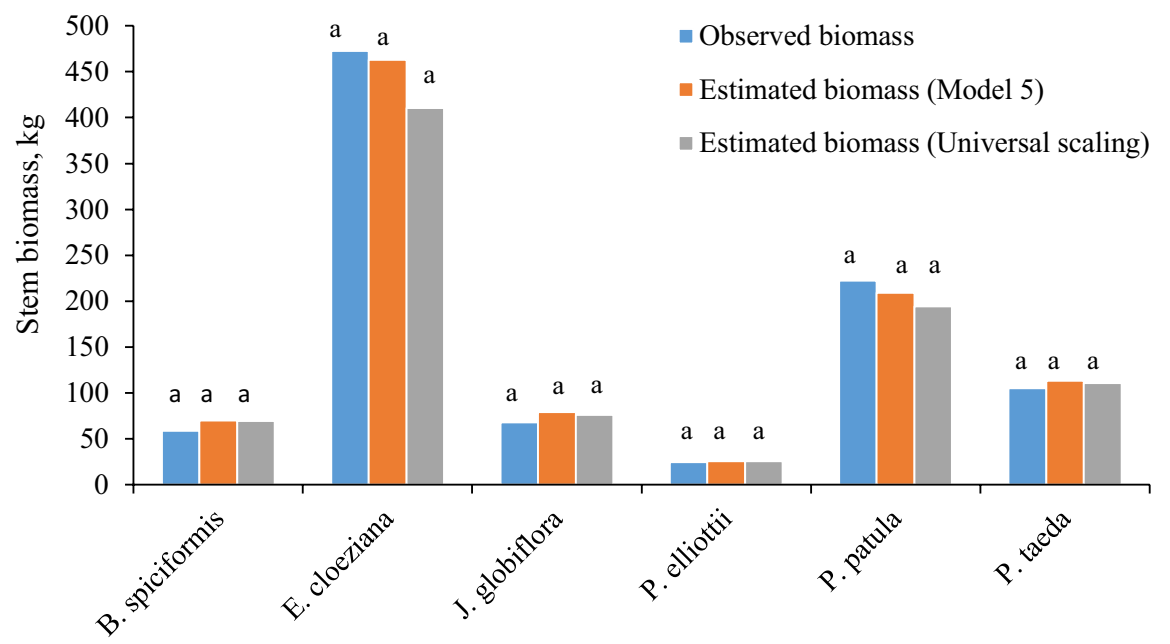

Tree species
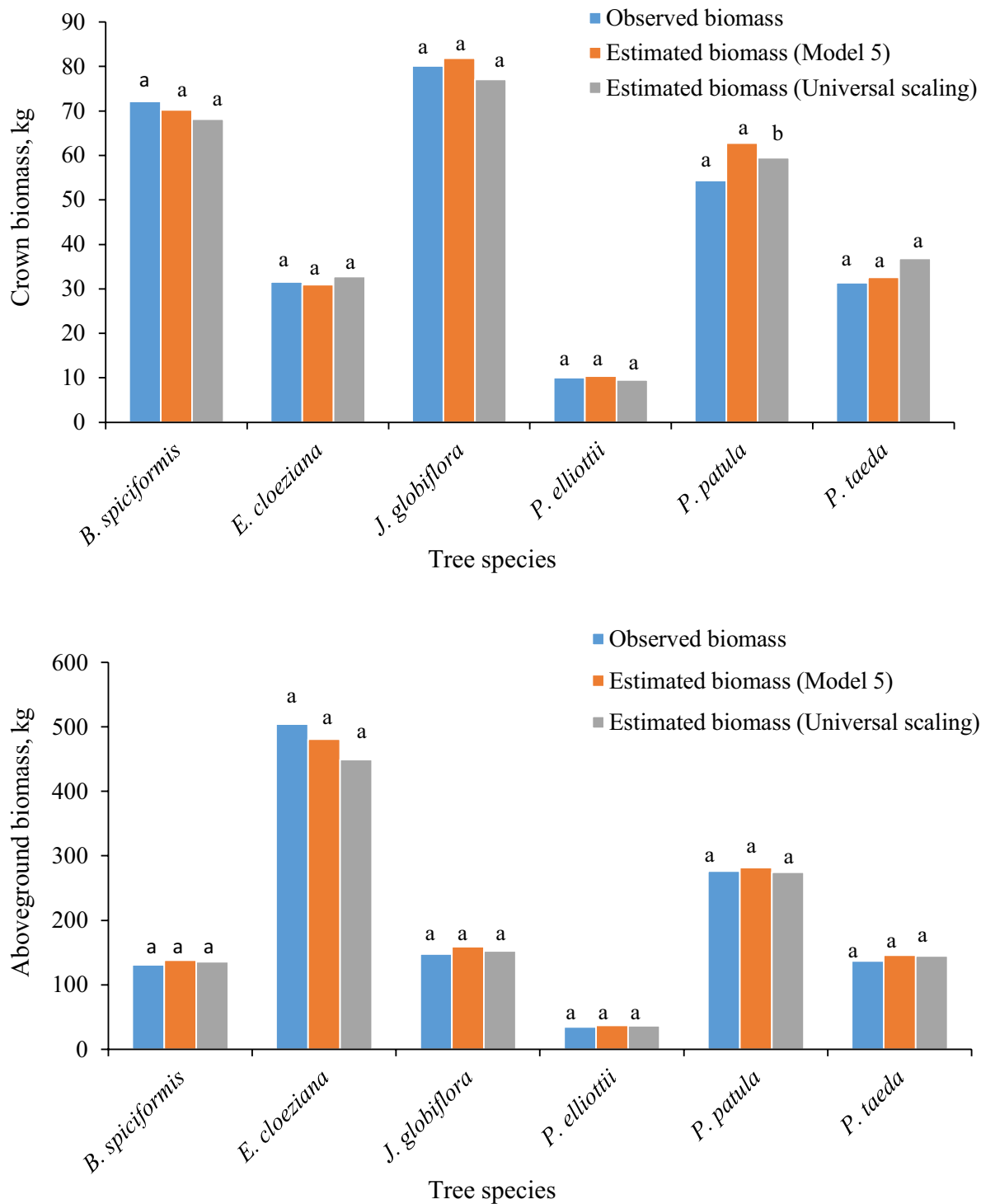
Table 7 Average $( \pm \mathrm{SE})$ BCEFs $\left(\mathrm{Mg} \mathrm{m}^{-3}\right)$ per species and per tree component

\begin{tabular}{llll}
\hline Tree species & $\mathrm{BCEF}_{\mathrm{c}}( \pm \mathrm{SE})$ & $\mathrm{BCEF}_{\mathrm{s}}( \pm \mathrm{SE})$ & $\mathrm{BCEF}_{\mathrm{t}}( \pm \mathrm{SE})$ \\
\hline B. spiciformis & $0.7357( \pm 0.0935)^{\mathrm{a}}$ & $0.8296( \pm 0.1080)^{\mathrm{a}}$ & $1.5652( \pm 0.1361)^{\mathrm{a}}$ \\
J. globiflora & $0.7045( \pm 0.0790)^{\mathrm{a}}$ & $0.6845( \pm 0.0367)^{\mathrm{ab}}$ & $1.3891( \pm 0.0790)^{\mathrm{a}}$ \\
E. cloeziana & $0.0566( \pm 0.0069)^{\mathrm{b}}$ & $0.6313( \pm 0.0188)^{\mathrm{b}}$ & $0.6878( \pm 0.0217)^{\mathrm{b}}$ \\
P. elliottii & $0.1564( \pm 0.0171)^{\mathrm{b}}$ & $0.3880( \pm 0.0087)^{\mathrm{bc}}$ & $0.5444( \pm 0.0206)^{\mathrm{b}}$ \\
P. patula & $0.1813( \pm 0.0419)^{\mathrm{b}}$ & $0.4992( \pm 0.0238)^{\mathrm{c}}$ & $0.6805( \pm 0.0522)^{\mathrm{b}}$ \\
P. taeda & $0.1223( \pm 0.0118)^{\mathrm{b}}$ & $0.4027( \pm 0.0094)^{\mathrm{c}}$ & $0.5250( \pm 0.0153)^{\mathrm{b}}$ \\
\hline
\end{tabular}

Means with different letters along rows differ significantly. The subscripts $\mathrm{c}, \mathrm{s}$, and $\mathrm{t}$ indicate crown, stem and total-tree (e.g., BCEFc = crown BCEF) than that reported by Henry et al. (2010) for tropical rain forests of Africa (69\%), by Peltier et al. (2007) for tropical dry forests (70\%) and by Henry et al. (2009) for tropical agroforestry systems in Kenya (62\%).

The different biomass allocation patterns of indigenous and exotic species could be a result of differences in stand density. The Miombo forest is composed of small trees (Table 1) and no more than 200 trees per hectare, while the plantations have upwards of 1000 trees per hectare. Xiang et al. (2011) maintained that stand density enhances the proportion of stem biomass but decreases biomass of branches. As a consequence of competition for light, exotic species have small branches and smaller quantities of leaves, resulting in smaller crowns than indigenous species which do not face limitations in light resources and growing space. Crown size has been reported to decrease with competition (van Laar and Akça 2007) as a result of natural pruning as a consequence of inter-tree competition for light and growing space and self-shading and shading by neighbouring trees.

\section{Biomass allometry}

Miombo species are the most important trees of southern Africa and of Mozambique (Ribeiro et al. 2015; Aquino et al. 2018), and Eucalyptus and Pinus species the most important reforestation species, planted mainly for commercial purposes (Blid 2014). Therefore, the accurate estimation of biomass of the Miombo species and the Eucalyptus and Pinus plantations is essential. The species-specific allometric models developed here predict biomass accurately for the exotic and indigenous species across the range of DBHs used to develop the models (Table 1) and have good applicability as tested using the independent samples. Nevertheless, it is not advisable to extrapolate beyond the data range as the results may be biased.

Crown models for the Miombo species had larger composite scaling exponents (up to $25 \%$ ) compared with those of the exotics, and composite scaling coefficients were constant for all species as a result of insignificant random scaling coefficients. As a result, the Miombo species had high predicted biomass for a given diameter and height compared with the exotic species. This is consistent with the finding that: (1) Miombo species store more biomass per stem volume than exotic species; (2) Miombo species allocate more biomass to crowns than to stems as compared to exotic species (Fig. 2); and, (3) per unit of DBH growth, the increment of crown biomass of Miombo is larger than that of exotic species. However, although Miombo species had larger increments of crown biomass per unit stem diameter growth and stored larger amounts of biomass per stem volume than the exotic species, due to their rapid growth, larger stem diameters and heights (on average), and stand density, the plantations store more biomass per tree and per unit area.

For all models, AGB and stem biomass had higher predictabilities than crown biomass. This is in agreement with Jagodziński et al. (2018a, b). Branch and crown biomass components are difficult to estimate with the same accuracy as stem biomass or total aboveground biomass (Vargas-Larreta et al. 2017). The high predictability of stem biomass and AGB models is attributed to the high correlation between these component biomasses and DBH (Fig. 1).

Diameter at breast height was the main predictor for estimating tree biomass components for all species, indigenous and exotics. For all components, the inclusion of height significantly improved the predictability of aboveground biomass and stem and crown biomass. Height as a second predictor substantially improved model precision (V) of stem biomass, AGB and crown biomass by $17 \%, 26 \%$, and $28 \%$, respectively, and model efficiency (EF) was improved by $23 \%, 23 \%$, and $28 \%$, respectively. The inclusion of height led to a substantial increase in predictive accuracy and ability. This is consistent with the findings by Pajtík et al. (2008), Xiang et al. (2011) and Vargas-Larreta et al. (2017). However, other researchers (Johansson 1999; Porté et al. 2002; Jenkins et al. 2003) reported that the inclusion of height does not lead to a significant increase in predictive ability.

Height is not directly measured in forest inventories and it is thus more susceptible to measuring error than $\mathrm{DBH}$ (Loetsch et al. 1973; Machado and Figueiredo Filho 2006; Sanquetta et al. 2006) and its measurement is not standardized (Sileshi 2014). Therefore, although with better predictability, models using height (Eqs. 6, 7) will lead to 

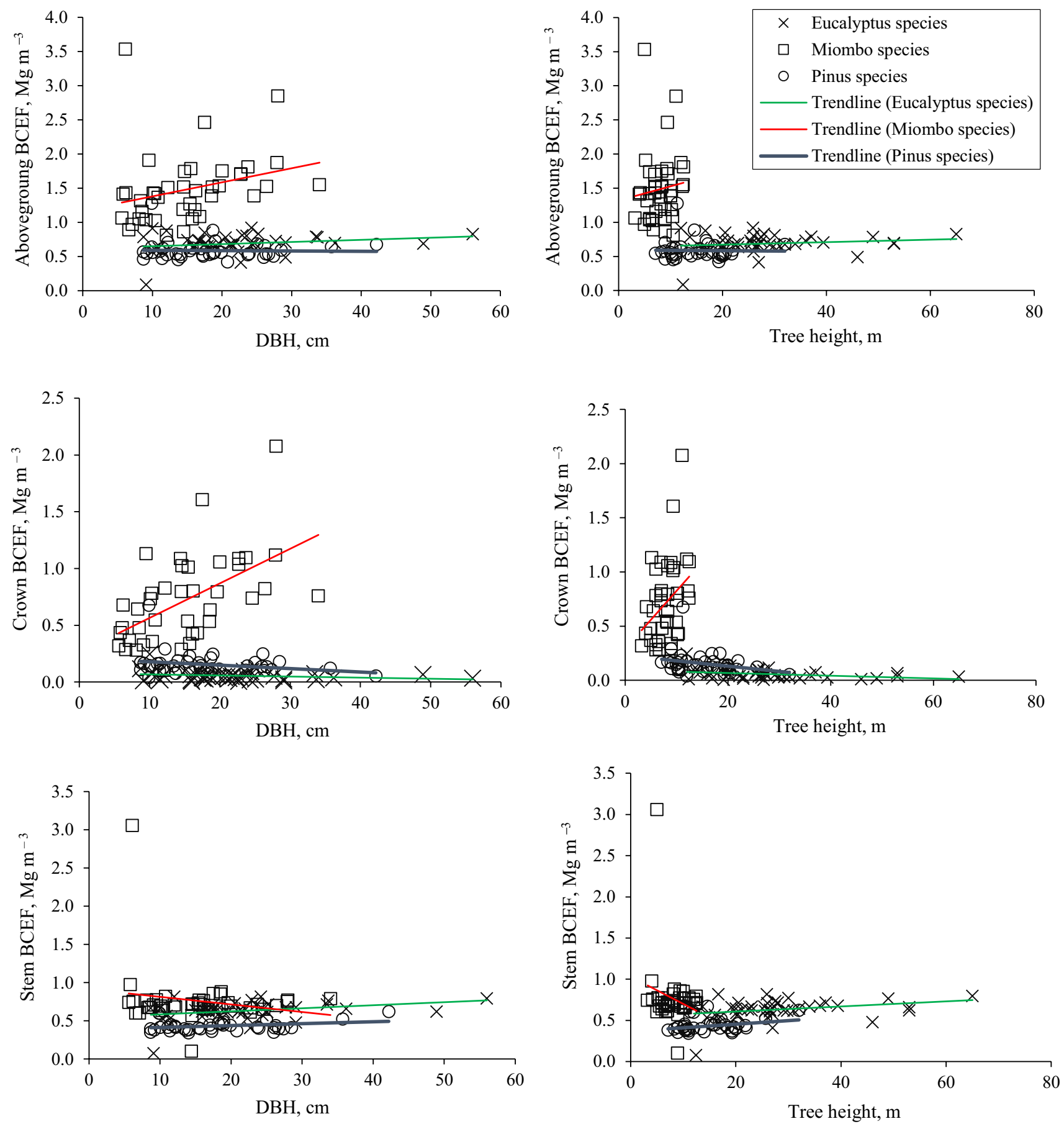

Fig. 5 Component BCEFs plotted against diameter at breast height and height

biased results because of inherent measurement errors of tree height. The inclusion of height in Eq. 4, either as a combined variable $\mathrm{D}^{2} \mathrm{H}$ (Eq. 7) or as a second predictor (Eq. 6), will introduce two sources of errors over and above those expected in Eq. 4 (Sileshi 2014): (1) errors due to measurement of height; and, (2) errors due to the estimation of model parameters. Moreover, 1-predictor biomass models, (DBH only models), are easier and faster to use and less expensive than 2-predictors models since the latter require height measurements which are expensive and time-consuming.

In biomass modelling, height is included in the model, either as a combined variable $\mathrm{D}^{2} \mathrm{H}$ (Eq. 7) or as a second variable, in addition to DBH (Eq. 6) (Zianis et al. 2005; Cienciala et al. 2006; Vejpustková et al. 2015). In this study, better prediction and accuracy were obtained when height 
was added as a second variable (Eq. 6). This contradicts Carvalho and Parresol (2003) and Bi et al. (2004) who obtained better estimates for the model with a combined predictor $\mathrm{D}^{2} \mathrm{H}$. However, our results are consistent with Vahedi et al. (2014) and Vejpustková et al. (2015).

Biomass conversion and expansion factors

Larger BCEF values were found for Miombo species and lower ones for the plantation species. Slow-growing species such as B. spiciformis and J. globiflora have high wood density, whereas fast-growing species (e.g., Eucalyptus and Pinus species) have low densities (Ouédraogo et al. 2013; Yeboah et al. 2014; Ramananantoandro et al. 2016). This explains why slow-growing Miombo species (Grundy 1995; Elifuraha et al. 2008; Chiteculo and Surovy 2018) had higher biomass conversion and expansion factors compared to exotic species as these factors are directly proportional to wood density (Pajtík et al. 2008; Schepaschenko et al. 2018). In other words, $\mathrm{BCEF}=\mathrm{BEF} \times \rho$, where $\mathrm{BEF}$ and $\rho$ are biomass expansion factors and wood density, respectively.

BCEFs have been reported to be reversely dependent on DBH and height (Brown et al. 1989; Lehtonen et al. 2004; Dutca et al. 2010; Sanquetta et al. 2011; Magalhães and Seifert 2015a) or to be independent of tree size (Marková and Pokorný 2011; Magalhães and Seifert 2015a). In this study, BCEF values of exotic species were not dependent on size; only crown BCEF of Miombo species were dependent on DBH and height. This is because the proportion of crown biomass on AGB increased with tree size, whereas that of stem biomass decreased (Fig. 3), resulting in BEF, and consequently $\mathrm{BCEF}$, to increase with increasing tree size. At the same time, the stability of the biomass conversion and expansion factors of exotic species over tree size is also related to the stability of the proportions of crown and stem biomass on AGB over tree size (Fig. 3).

Dutca et al. (2010) maintained that the reverse relationship between BEF and tree size is a result of an inverse relationship between wood density and size. This suggests that the direct dependence of crown BCEF of Miombo species to tree size may be due to the direct relationship between branch wood density and size. Increasing wood density with age and tree size has been reported by various researchers (Pajtík et al. 2008; Nock et al. 2009; Henry et al. 2010; Deng et al. 2014). However, there are also studies showing that wood density does not vary with stem diameter (Ramananantoandro et al. 2016; Fajardo 2018), whereas others have reported that wood density decreases with tree age and size (Pajtík et al. 2008; Liepiňš et al. 2017). This pattern of variability in wood density explains the variability of patterns of BCEF with tree size (Fig. 3).

Stem, crown, and aboveground BCEF values of B. spiciformis and J. globiflora are larger than those observed by Magalhães and Mate (2018) for other Miombo species, Umbila (Pterocarpus angolensis DC.) and Chanfuta (Afzelia quanzensis Welw.) except for Panga-panga (Millettia stuhImannii Taub.), and are also larger for other Mozambican indigenous species such as Mecrusse (Androstachys johnsonii Prain) (Magalhães and Seifert 2015a) and Mopane (Colophospermum mopane (Kirk ex Banth.) Kirk ex J. Leonard) (Magalhães and Mate 2018). It was assumed that the differences in BCEF are attributed to the differences in climate, soil conditions, altitude, and species.

The majority of variation of the biomass conversion and expansion factors was attributed uniquely to species rather than to stem diameter and height, and this is consistent with Luo et al. (2014) who found that BCEF exhibited remarkable variation across forest types.

\section{Conclusions}

This study provided species-species biomass allometric models and biomass conversion and expansion factors for the Miombo species B. spiciformis and J. globiflora and for exotic species of Eucalyptus cloeziana, Pinus elliotti, Pinus patula, and Pinus taeda growing in highlands of Manica province, Mozambique. The allometric biomass models, for all tree components, had an acceptable predictive accuracy and ability. The highest predictive accuracy and ability was found with models with tree height as a second variable $\left(Y=\phi_{0 i} \times D^{\phi_{1 i}} \times H^{\phi_{2 i}}+\varepsilon\right)$. The Miombo species had larger increments of crown biomass per unit of stem diameter as seen by their larger scaling exponents. Similarly, they stored larger amounts of biomass per stem volume unit, i.e., their biomass conversion and expansion factors were up to 13-fold larger than those of the exotic species. The majority of the variation of these factors (up to 99\%) was attributed uniquely to species rather than to diameter or height. Although with relatively lower, yet acceptable predictive accuracy and ability, the model fitted under the constraint of the allometric universal scaling law $\left(Y=\phi_{0 i} \times D^{8 / 3}+\varepsilon\right)$ showed that the universal exponent $(8 / 3)$ was data acceptable for both indigenous and exotic tree species.

Acknowledgements Thanks are addressed to the field team (João Paulino from the Forest Harvesting Division, Romano Guiamba from the Soil Laboratory) and to the anonymous reviewers of the manuscript. Thanks are also extended to the staff of the Centro Agroflorestal de Machipanda, Prof. Ernesto Uetimane and Mr Alfredo, who provided accommodation, transportation and other facilities for data collection.

Open Access This article is licensed under a Creative Commons Attribution 4.0 International License, which permits use, sharing, adaptation, distribution and reproduction in any medium or format, as long as you give appropriate credit to the original author(s) and the source, provide a link to the Creative Commons licence, and indicate if changes were made. The images or other third party material in this article are included in the article's Creative Commons licence, unless indicated otherwise in a credit line to the material. If material is not included in 
the article's Creative Commons licence and your intended use is not permitted by statutory regulation or exceeds the permitted use, you will need to obtain permission directly from the copyright holder. To view a copy of this licence, visit http://creativecommons.org/licenses/by/4.0/.

\section{References}

Akaike H (1973) Information theory and extension of the maximum likelihood principle. In: 2nd International symposium in information theory. Akademiai Kiado, Budapest, pp 267-281

Annighöfer P, Ameztegui A, Ammer C, Balandier P, Bartsch N, Bolte A, Coll L, Collet C, Ewald J, Frischbier N, Gebereyesus T, Haase J, Hamm T, Hirschfelder B, Huth F, Kändler G, Kahl A, Kawaletz H, Kuehne C, Lacointe A, Lin N, Löf M, Malagoli P, Marquier A, Müller S, Promberger S, Provendier D, Röhle H, Sathornkich J, Schall P, Scherer-Lorenzen M, Schröder J, Seele C, Weidig J, Wirth C, Wolf H, Wollmerstädt J, Mund M (2016) Species-specific and generic biomass equations for seedlings and saplings of European tree species. Eur J For Res 135:313-329. https://doi.org/10.1007/s10342-016-0937-z

Aquino A, Lim C, Kaechele K, Taquidir M (2018) Mozambique Mozambique Country Forest Note. Maputo

Bervian G, Fontoura NF, Haimovici M (2006) Statistical model of variable allometric growth: Otolith growth in Micropogonias furnieri (Actinopterygii, Sciaenidae). J Fish Biol 68:196-208. https://doi. org/10.1111/j.0022-1112.2006.00890.x

Bi HQ, Turner J, Lambert MJ (2004) Additive biomass equations for native eucalypt forest tress of temperate Australia. Trees Struct Funct 18:467-479. https://doi.org/10.1007/s00468-004-0333-Z

Blid N (2014) Indústria florestal e movimento sindical em Moçambique. Maputo

Blujdea VNB, Pilli R, Dutca I, Ciuvat L, Abrudan IV (2012) Allometric biomass equations for young broadleaved trees in plantations in Romania. For Ecol Manag 264:172-184. https://doi. org/10.1016/j.foreco.2011.09.042

Bolte A, Rahmann T, Kuhr M, Pogoda P, Murach D, Gadow KV (2004) Relationships between tree dimension and coarse root biomass in mixed stands of European beech (Fagus sylvatica L.) and Norway spruce (Picea abies [L.] Karst.). Plant Soil 264:1-11. https ://doi.org/10.1023/B:PLSO.0000047777.23344.a3

Brown S, Gillespie AJR, Lugo AE (1989) Biomass estimation methods for tropical forests with applications to forest inventory data. For Sci 35:881-902

Brown S, Schroeder P, Kern SJ (1999) Spatial distribution of biomass in forests of the eastern USA. For Ecol Manag 123:81-90. https ://doi.org/10.1093/forestscience/43.3.424

Calama R, Montero G (2004) Interregional nonlinear height-diameter model with random coefficients for stone pine in Spain. Can J For Res 34:150-163. https://doi.org/10.1139/x03-199

Carvalho JP, Parresol BR (2003) Additivity in tree biomass components of Pyrenean oak (Quercus pyrenaica Willd.). For Ecol Manag 179:269-276. https://doi.org/10.1016/S0378-1127(02)00549-2

Castro I, Casado MÁ, Ramirez-sanz L, Migue JM, Costa M, Pineda D (1996) Funciones de estimación de la biomasa aérea de varias especies del matorral mediterráneo del centro de la península Ibérica. Orsis Org i Sist 11:107-116

Chambers JQ, dos Santos J, Ribeiro R, Higuchi N (2001) Tree damage, allometric relationships, and aboveground net primary production in a tropical forest. For Ecol Manag 152:73-84

Chen DS, Huang XZ, Zhang SG, Sun XM (2017) Biomass modeling of larch (Larix spp.) plantations in China based on the mixed model, dummy variable model, and Bayesian hierarchical model. Forests 8:5-8. https://doi.org/10.3390/f8080268

Chen LC, Guan X, Li HM, Wang QK, Zhang WD, Yang QP, Wang SL (2019) Spatiotemporal patterns of carbon storage in forest ecosystems in Hunan Province, China. For Ecol Manag 432:656666. https://doi.org/10.1016/j.foreco.2018.09.059

Chiteculo V, Surovy P (2018) Dynamic patterns of trees species in miombo forest and management perspectives for sustainable production-case study in Huambo Province, Angola. Forests. https://doi.org/10.3390/f9060321

Cienciala E, Černý M, Tatarinov F, Apltauer J, Exnerová Z (2006) Biomass functions applicable to Scots pine. Trees Struct Funct 20:483-495. https://doi.org/10.1007/s00468-006-0064-4

Coll L, Potvin C, Messier C, Delagrange S (2008) Root architecture and allocation patterns of eight native tropical species with different successional status used in open-grown mixed plantations in Panama. Trees Struct Funct 22:585-596. https://doi. org/10.1007/s00468-008-0219-6

Correia AC, Tomé M, Carlos P, Sónia F, Dias A, Freire J, Carvalho PO, Pereira JS (2010a) Biomass allometry and carbon factors for a Mediterranean pine (Pinus pinea L.) in Portugal. For Syst 19:418-433. https://doi.org/10.5424/fs/2010193-9082

Correia AC, Tomé M, Pacheco CA, Faias S, Dias AC, Freire J, Carvalho PO, Pereira JS (2010b) Alometría de la biomasa y factores de carbono para un pino Mediterráneo (Pinus pinea L.) en Portugal. For Syst 19:418-433. https://doi.org/10.5424/fs/20101 93-9082

Deng XW, Zhang LY, Lei PF, Xiang WH, Yan WD (2014) Variations of wood basic density with tree age and social classes in the axial direction within Pinus massoniana stems in Southern China. Ann For Sci 71:505-516. https://doi.org/10.1007/s13595-013-0356-y

Dutca I, Abrudan IV, Stancioiu PT, Blujdea V (2010) Biomass conversion and expansion factors for young Norway spruce (Picea abies (L.) Karst.) trees planted on non-forest lands in Eastern Carpathians. Not Bot Hortic Agrobot Cluj-Napoca 38:286-292

Elifuraha E, Nöjd P, Mbwambo L (2008) Short term growth of miombo tree species at Kitulangalo. Work Pap Finnish For Res Inst 98:37-45

Enquist BJ (2002) Universal scaling in tree and vascular plant allometry: toward a general quantitative theory linking plant form and function from cells to ecosystems. Tree Physiol 22:1045-1064. https://doi.org/10.1093/treephys/22.15-16.1045

Fajardo A (2018) Insights into intraspecific wood density variation and its relationship to growth, height and elevation in a treeline species. Plant Biol 20:456-464. https://doi.org/10.1111/plb.12701

Fan SH, Guan FX, Xu XL, Forrester DI, Ma W, Tang XL (2016) Ecosystem carbon stock loss after land use change in subtropical forests in China. Forests. https://doi.org/10.3390/f7070142

Fang YR, Zou XJ, Lie ZY, Xue L (2018) Variation in organ biomass with changing climate and forest characteristics across Chinese forests. Forests 9:1-11. https://doi.org/10.3390/f9090521

Fehrmann L, Kleinn C (2006) General considerations about the use of allometric equations for biomass estimation on the example of Norway spruce in central Europe. For Ecol Manag 236:412-421. https://doi.org/10.1016/j.foreco.2006.09.026

Feng CY, Wang HY, Lu NJ, Chen T, He H, Lu Y, Tu XM (2014) Log-transformation and its implications for data analysis. Shanghai Arch Psychiatry 26:105-109. https://doi.org/10.3969/j. issn.1002-0829.2014.02

Fournier RA, Luther JE, Guindon L, Lambert MC, Piercey D, Hall RJ, Wulder MA (2003) Mapping aboveground tree biomass at the stand level from inventory information: test cases in Newfoundland and Quebec. Can J For Res 33:1846-1863. https://doi. org/10.1139/x03-099 
Fu XL, Shao MA, Wei XR, Horton R (2010) Soil organic carbon and total nitrogen as affected by vegetation types in Northern Loess Plateau of China. Geoderma 155:31-35. https://doi. org/10.1016/j.geoderma.2009.11.020

Furnival G (1961) An index for comparing equations used in constructing volume tables. For Sci 7:337-341

Goussanou CA, Guendehou S, Assogbadjo AE, Kaire M, Sinsin B, Cuni-Sanchez A (2016) Specific and generic stem biomass and volume models of tree species in a West African tropical semideciduous forest. Silva Fenn 50:1-22. https://doi.org/10.14214 /sf. 1474

Grundy IM (1995) Wood biomass estimation in dry miombo woodland in Zimbabwe. For Ecol Manag 72:109-117. https://doi. org/10.1016/0378-1127(94)03467-B

Guedes BS, Olsson BA, Egnell G, Sitoe AA, Karltun E (2018) Plantations of Pinus and Eucalyptus replacing degraded mountain miombo woodlands in Mozambique significantly increase carbon sequestration. Glob Ecol Conserv 14:1-13. https://doi. org/10.1016/j.gecco.2018.e00401

Guedes BS, Olsson BA, Karltun E (2016) Effects of 34-year-old Pinus taeda and Eucalyptus grandis plantations on soil carbon and nutrient status in former miombo forest soils. Glob Ecol Conserv 8:190-202. https://doi.org/10.1016/j.gecco.2016.09.005

Henry M, Besnard A, Asante WA, Eshun J, Adu-Bredu S, Valentini R, Bernoux M, Saint-André L (2010) Wood density, phytomass variations within and among trees, and allometric equations in a tropical rainforest of Africa. For Ecol Manag 260:1375-1388. https://doi.org/10.1016/j.foreco.2010.07.040

Henry M, Tittonell P, Manlay RJ, Bernoux M, Albrecht A, Vanlauwe B (2009) Biodiversity, carbon stocks and sequestration potential in aboveground biomass in smallholder farming systems of western Kenya. Agric Ecosyst Environ 129:238-252. https://doi. org/10.1016/j.agee.2008.09.006

Houghton RA (2007) Balancing the global carbon budget. Annu Rev Earth Planet Sci 35:313-347. https://doi.org/10.1146/annur ev.earth.35.031306.140057

Jagodziński AM, Dyderski MK, Gęsikiewicz K, Horodecki P, Cysewska A, Wierczyńska S, Maciejczyk K (2018a) How do tree stand parameters affect young Scots pine biomass? Allometric equations and biomass conversion and expansion factors. For Ecol Manag 409:74-83. https://doi.org/10.1016/j.forec o.2017.11.001

Jagodziński AM, Dyderski MK, Gęsikiewicz K, Horodecki P (2018b) Tree- and stand-level biomass estimation in a Larix decidua Mill. Chronosequence. Forests. https://doi.org/10.3390/f9100587

Jenkins JC, Chojnacky DC, Heath LS, Birdsey RA (2003) Nationalscale biomass estimators for United States tree species. For Sci 49:12-35. https://doi.org/10.1093/forestscience/49.1.12

Johansson T (1999) Biomass equations for determining fractions of pendula and pubescent birches growing on abandoned farmland and some practical implications. Biomass Bioenergy 16:223238. https://doi.org/10.1016/S0961-9534(98)00075-0

Ketterings QM, Coe R, Van Noordwijk M, Ambagau Y, Palm CA (2001) Reducing uncertain in the use of allometric biomass equation for predciting above-ground tree biomass in mixed secondary forests. For Ecol Manag 146:199-209

Lehtonen A, Mäkipää R, Heikkinen J, Sievänen R, Liski J (2004) Biomass expansion factors (BEFs) for Scots pine, Norway spruce and birch according to stand age for boreal forests. For Ecol Manag 188:211-224. https://doi.org/10.1016/j.forec o.2003.07.008

Li HT, Han XG, Wu JG (2005) Lack of evidence for 3/4 scaling of metabolism in terrestrial plants. J Integr Plant Biol 47:11731183. https://doi.org/10.1111/j.1744-7909.2005.00167.x
Liepiņš J, Ivanovs J, Lazdiņš A, Jansons J, Liepiņš K (2017) Mapping of basic density within European aspen stems in Latvia. Silva Fenn 51:1-9. https://doi.org/10.14214/sf.7798

Loetsch F, Zohrer F, Haller KE (1973) Forst inventory. BLV, Munich

Lozano-García B, Parras-Alcántara L (2013) Land use and management effects on carbon and nitrogen in Mediterranean Cambisols. Agric Ecosyst Environ 179:208-214. https://doi.org/10.1016/j. agee.2013.07.009

Luo YJ, Zhang XQ, Wang XK, Ren Y (2014) Dissecting variation in biomass conversion factors across China's forests: implications for biomass and carbon accounting. PLoS ONE. https:// doi.org/10.1371/journal.pone.0094777

Machado SA, Figueiredo Filho A (2006) Dendrometria, 2nd edn. Editora UNICENTRO, Paraná

Magalhães TM (2014) Análise do Sistema de Exploração dos Recursos Florestais em Moçambique. Maputo

Magalhães TM, Mate RS (2018) Least squares-based biomass conversion and expansion factors best estimate biomass than ratiobased ones: statistical evidences based on tropical timber species. MethodsX 5:30-38. https://doi.org/10.1016/j.mex.2018.01.005

Magalhães TM, Seifert T (2015a) Tree component biomass expansion factors and root-to-shoot ratio of Lebombo ironwood: Measurement uncertainty. Carbon Balance Manag. https://doi. org/10.1186/s13021-015-0019-4

Magalhães TM, Seifert T (2015b) Biomass modelling of Androstachys johnsonii Prain: a comparison of three methods to enforce additivity. Int J For Res 2015:1-17. https://doi. org/10.1155/2015/878402

Makungwa SD, Chittock A, Skole DL, Kanyama-Phiri GY, Woodhouse IH (2013) Allometry for biomass estimation in Jatropha trees planted as boundary hedge in farmers' fields. Forests 4:218-233. https://doi.org/10.3390/f4020218

Marková I, Pokorný R (2011) Allometric relationships for the estimation of dry mass of aboveground organs in young highland Norway spruce stand. Acta Univ Agric Silvic Mendelianae Brun 59:217-224. https://doi.org/10.11118/actaun201159060217

Návar J (2009) Biomass component equations for Latin American species and groups of species. Ann For Sci. https://doi.org/10.1051/ forest $/ 2009001$

Niklas KJ (2006) Scaling the paths of resistance. New Phytol 169:219_ 222. https://doi.org/10.1111/j.1469-8137.2005.01629.x

Nimon K, Oswald F, Roberts JK (2015) Yhat: interpreting regression effects (R Package Version 2.0-0)

Nock CA, Geihofer D, Grabner M, Baker PJ, Bunyavejchewin S, Hietz $P(2009)$ Wood density and its radial variation in six canopy tree species differing in shade-tolerance in western Thailand. Ann Bot 104:297-306. https://doi.org/10.1093/aob/mcp118

Opik H, Rolfe S (2005) The physiology of flowering plants, 4th edn. Cambridge University Press, Cambridge

Ouédraogo DY, Mortier F, Gourlet-Fleury S, FreyconV PN (2013) Slow-growing species cope best with drought: evidence from long-term measurements in a tropical semi-deciduous moist forest of Central Africa. J Ecol 101:1459-1470. https://doi. org/10.1111/1365-2745.12165

Overman JPM, Witte HJL, Saldarriaga JG (1994) Evaluation of regression models for above-ground biomass determination in Amazon rainforest. J Trop Ecol 10:207-218. https://doi.org/10.1017/ S0266467400007859

Packard GC (2013) Is logarithmic transformation necessary in allometry? Biol J Linn Soc 109:476-486. https://doi.org/10.1111/ bij. 12038

Packard GC, Boardman TJ (2008) Model selection and logarithmic transformation in allometric analysis. Physiol Biochem Zool 81:496-507. https://doi.org/10.1086/589110 
Pajtík J, Konôpka B, Lukac M (2008) Biomass functions and expansion factors in young Norway spruce (Picea abies [L.] Karst) trees. For Ecol Manag 256:1096-1103. https://doi.org/10.1016/j.forec o.2008.06.013

Pan Y, Birdsey RA, Fang J, Houghton R, Kauppi PE, Kurz WA, Phillips OL, Shvidenko A, Lewis SL, Canadell JG, Ciais P, Jackson RB, Pacala SW, McGuire AD, Piao S, Rautiainen A, Sitch S, Hayes D (2011) A large and persistent carbon sink in the World's forests. Science 80(333):988-993. https://doi.org/10.1126/scien ce. 1201609

Parresol BR (2001) Additivity of nonlinear biomass equations. Can J For Res 31:865-878. https://doi.org/10.1139/x00-202

Parresol BR (1999) Assessing tree and stand biomass: a review with examples and critical comparisons. For Sci 45:573-593

Paul KI, Larmour J, Specht A, Zerihun A, Ritson P, Roxburgh SH, Sochacki S, Lewis T, Barton CVM, England JR, Battaglia M, O'Grady A, Pinkard E, Applegate G, Jonson J, Brooksbank K, Sudmeyer R, Wildy D, Montagu KD, Bradford M, Butler D, Hobbs $\mathrm{T}$ (2019) Testing the generality of below-ground biomass allometry across plant functional types. For Ecol Manag 432:102-114. https ://doi.org/10.1016/j.foreco.2018.08.043

Paul KI, Roxburgh SH, England JR, Ritson P, Hobbs T, Brooksbank K, Raison RJ, Larmour JS, Murphy S, Norris J, Neumann C, Lewis T, Jonson J, Carter JL, McArthur G, Barton C, Rose B (2013a) Development and testing of allometric equations for estimating above-ground biomass of mixed-species environmental plantings. For Ecol Manag 310:483-494. https://doi.org/10.1016/j.forec o.2013.08.054

Paul KI, Roxburgh SH, Ritson P, Brooksbank K, England JR, Larmour JS, Raison RJ, Peck A, Wildy DT, Sudmeyer RA, Giles R, Carter J, Bennett R, Mendham DS, Huxtable D, Bartle JR (2013b) Testing allometric equations for prediction of above-ground biomass of mallee eucalypts in southern Australia. For Ecol Manag 310:10051015. https://doi.org/10.1016/j.foreco.2013.09.040

Peltier R, Forkong CN, Manlay R, Henry M, Morillon V (2007) Évaluation du stock de carbone et de la productivité en bois d'un parc à karités du Nord-Cameroun. Bois forêts des Trop 294:39-50. https ://doi.org/10.19182/bft2007.294.a20332

Picard N (2012) Manual for building tree volume and biomass allometric equations. FAO, Rome

Pilli R, Anfodillo T, Carrer M (2006) Towards a functional and simplified allometry for estimating forest biomass. For Ecol Manag 237:583-593. https://doi.org/10.1016/j.foreco.2006.10.004

Pinheiro J, Bates D, DebRoy S, Sarkar D, Heisterkamp S, Willigen B Van (2019) NLME: linear and nonlinear mixed effects models. $\mathrm{R}$ package version 3.1-142. R Found. Stat. Comput. Vienna 335.

Porté A, Trichet P, Bert D, Loustau D (2002) Allometric relationships for branch and tree woody biomass of Maritime pine (Pinus pinaster Ait.). For Ecol Manag 158:71-83. https://doi.org/10.1016/S0378 $-1127(00) 00673-3$

R Core Team (2020) A language and environment for statistical computing

Ramananantoandro T, Ramanakoto MF, Rajoelison GL, Randriamboavonjy JC, Rafidimanantsoa HP (2016) Influence of tree species, tree diameter and soil types on wood density and its radial variation in a mid-altitude rainforest in Madagascar. Ann For Sci 73:1113-1124. https://doi.org/10.1007/s13595-016-0576-Z

Ribeiro NS, Syampungani S, Matakala NM, Nangoma D, Ribeiro-Barros AI (2015) Miombo woodlands research towards the sustainable use of ecosystem services in southern Africa. In: Jacob-Lopes E, Zepka LQ (eds) Renewable resources and biorefineries. IntechOpen, London, pp 475-491

Salis SM, Assis MA, Mattos PP, Pião ACS (2006) Estimating the aboveground biomass and wood volume of savanna woodlands in Brazil's Pantanal wetlands based on allometric correlations. For Ecol Manag 228:61-68. https://doi.org/10.1016/j.foreco.2006.02.025
Sanquetta CR, Corte AP, da Silva F (2011) Biomass expansion factor and root-to-shoot ratio for Pinus in Brazil. Carbon Balance Manag 6:6. https://doi.org/10.1186/1750-0680-6-6

Sanquetta CR, Watzlawick LF, Côrte APD, Fernandes LA (2006) Inventários florestais: planejamento e execução. Multi-Graphic Gráfica e Editora, Curitiba

Schepaschenko D, Moltchanova E, Shvidenko A, Blyshchyk V, Dmitriev E, Martynenko O, See L, Kraxner F (2018) Improved estimates of biomass expansion factors for Russian forests. Forests 9:1-23. https ://doi.org/10.3390/f9060312

Schroeder P, Brown S, Mo J, Birdsey R, Cieszewski C (1997) Biomass estimation for temperate broadleaf forests of the United States using inventory data. For Scten 43:424-434

Sileshi GW (2014) A critical review of forest biomass estimation models, common mistakes and corrective measures. For Ecol Manag 329:237-254. https://doi.org/10.1016/j.foreco.2014.06.026

Soares P, Tomé M, Skovsgaard JP, Vanclay JK (1995) Evaluating a growth model for forest management using continuous forest inventory data. For Ecol Manag 71:251-265. https://doi. org/10.1016/0378-1127(94)06105-R

Spiess A-N, Neumeyer N (2010) An evaluation of R2 as an inadequate measure for nonlinear models in pharmacological and biochemical research: a Monte Carlo approach. BMC Pharmacol 10:6. https:// doi.org/10.1186/1471-2210-10-6

Ter-Mikaelian MT, Korzukhin MD (1997) Biomass equations for sixtyfive North American tree species. For Ecol Manag 97:1-24. https ://doi.org/10.1016/S0378-1127(97)00019-4

Trubat R, Cortina J, Vilagrosa A (2012) Root architecture and hydraulic conductance in nutrient deprived Pistacia lentiscus L. seedlings. Oecologia 170:899-908. https://doi.org/10.1007/s0044 2-012-2380-2

Vahedi AA, Mataji A, Babayi-Kafaki S, Eshaghi-Rad J, Hodjati SM, Djomo A (2014) Allometric equations for predicting aboveground biomass of beech-hornbeam stands in the Hyrcanian forests of Iran. J For Sci 60:236-247. https://doi.org/10.17221/39/2014-jfs

van Laar A, Akça A (2007) Forest mensuration. Springer, Dordrecht

Vanclay JK, Skovsgaard JP (1997) Evaluating forest growth models. Ecol Modell 98:1-12. https://doi.org/10.1016/S0304-3800(96)01932-1

Vargas-Larreta B, López-Sánchez CA, Corral-Rivas JJ, López-Martínez JO, Aguirre-Calderón CG, Álvarez-González JG (2017) Allometric equations for estimating biomass and carbon stocks in the temperate forests of North-Western Mexico. Forests 8:1-20. https://doi. org/10.3390/f8080269

Vejpustková M, Zahradník D, Čihák T, Šrámek V (2015) Models for predicting aboveground biomass of European beech (Fagus sylvatica L.) in the Czech Republic. J For Sci 61:45-54. https://doi. org/10.17221/100/2014-JFS

Vieilledent G, Vaudry R, Andriamanohisoa SFD, Rakotonarivo OS, Randrianasolo HZ, Razafindrabe HN, Rakotoarivony CB, Ebeling J, Rasamoelina M (2012) A universal approach to estimate biomass and carbon stock in tropical forests using generic allometric models. Ecol Appl 22:572-583. https://doi.org/10.1890/11-0039.1

von Gadow K, Hui G (1999) Modelling forest development. Kluwer, Dordrecht

West GB, Brown JH, Enquist BJ (1999) A general model for the structure and allometry of plant vascular systems. Nature 400:664-667. https ://doi.org/10.1038/23251

Xiang WH, Liu SH, Deng XW, Shen AH, Lei XD, Tian DL, Zhao MF, Peng CH (2011) General allometric equations and biomass allocation of Pinus massoniana trees on a regional scale in southern China. Ecol Res 26:697-711. https://doi.org/10.1007/s1128 4-011-0829-0

Yeboah D, Burton AJ, Storer AJ, Opuni-Frimpong E (2014) Variation in wood density and carbon content of tropical plantation tree species from Ghana. New For 45:35-52. https://doi.org/10.1007/s1105 6-013-9390-8 
Zapata-Cuartas M, Sierra CA, Alleman L (2012) Probability distribution of allometric coefficients and Bayesian estimation of aboveground tree biomass. For Ecol Manag 277:173-179. https://doi. org/10.1016/j.foreco.2012.04.030

Zhang H, Song TQ, Wang KL, Wang GX, Liao JX, Xu GH, Zeng FP (2015) Biogeographical patterns of forest biomass allocation vary by climate, soil and forest characteristics in China. Environ Res Lett. https://doi.org/10.1088/1748-9326/10/4/044014

Zianis D, Mencuccini M (2004) On simplifying allometric analyses of forest biomass. For Ecol Manag 187:311-332. https://doi. org/10.1016/j.foreco.2003.07.007
Zianis D, Muukkonen P, Mäkipää R, Mencuccini M (2005) Biomass and stem volume equations for tree species in Europe. Silva Fennica Monographs 4. 64p

Publisher's Note Springer Nature remains neutral with regard to jurisdictional claims in published maps and institutional affiliations. 